Engineer Research and

Development Center

Environmental Quality/Installations (EQ/I)

\title{
Corrosion and Migration of Zero-Valent Depleted Uranium Products in Soil
}

Victor F. Medina, Michelle Wynter, Steven L. Larson,

Robert D. Moser, and Catherine C. Nestler 
The U.S. Army Engineer Research and Development Center (ERDC) solves the nation's toughest engineering and environmental challenges. ERDC develops innovative solutions in civil and military engineering, geospatial sciences, water resources, and environmental sciences for the Army, the Department of Defense, civilian agencies, and our nation's public good. Find out more at www.erdc.usace.army.mil.

To search for other technical reports published by ERDC, visit the ERDC online library at http://acwc.sdp.sirsi.net/client/default. 


\section{Corrosion and Migration of Zero-Valent Depleted Uranium Products in Soil}

Victor F. Medina, Michelle Wynter, and Steven L. Larson

U.S. Army Engineer Research and Development Center (ERDC)

Environmental Laboratory (EL)

3909 Halls Ferry Rd.

Vicksburg, MS 39180

Robert D. Moser

U.S. Army Engineer Research and Development Center (ERDC)

Geotechnical and Structures Laboratory (GSL)

3909 Halls Ferry Rd

Vicksburg, MS 39180

Catherine C. Nestler

Applied Research Associates, Inc.

119 Monument Place

Vicksburg, MS 39180

Final Report

Approved for public release; distribution is unlimited.

Prepared for Headquarters, U.S. Army Corps of Engineers

Washington, DC 20314-1000

Under Department of Defense Appropriations Act Program Element 0603728A, "Depleted Uranium (DU) Clearance from DOD Ranges" 


\section{Abstract}

Zero-valent metallic depleted uranium (DU) penetrators exposed in the environment after firing frequently undergo corrosion. Unlike previous field studies, this report evaluates metallic DU corrosion in a controlled laboratory setting using a 28 day wet-dry cycling method to simulate environmental corrosion. Carried out in construction-grade sand, the study evaluated the effect of three solutions: deionized (DI) water, $3.5 \%$ salt $(\mathrm{NaCl})$ solution, and an acid solution. Two oxidation products in the reactors were noted at 14 days, both in the sand and on the penetrator. Oxidation product migrated to the sand media; the higher percentage of migration came from the corrosion fluid that produced the least amount of corrosion. Changes in mass percentages of uranium and oxygen correlated with density changes, as evidenced by relative brightness, to show differences in corrosion. Other elements (sodium, magnesium, iron, and calcium) increased in mass percentage with increasing corrosion. Five soil types were also used to corrode DU. Multiple soil physical and chemical characteristics appear to contribute to differences in the rates of corrosion, including soil $\mathrm{pH}$, percentage of soil fines, and total organic carbon content. These studies suggest that limiting moisture and salt exposure could reduce corrosion of exposed DU and subsequent migration.

DISCLAIMER: The contents of this report are not to be used for advertising, publication, or promotional purposes. Citation of trade names does not constitute an official endorsement or approval of the use of such commercial products. All product names and trademarks cited are the property of their respective owners. The findings of this report are not to be construed as an official Department of the Army position unless so designated by other authorized documents. 


\section{Contents}

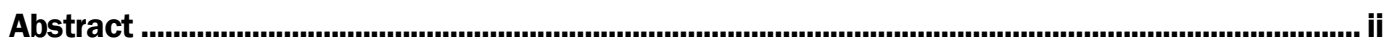

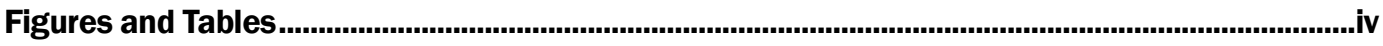

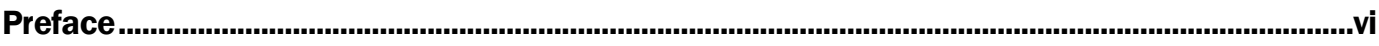

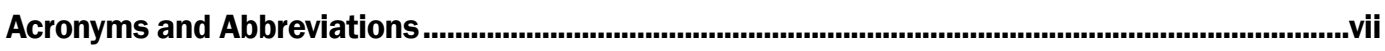

1 Introduction ................................................................................................................................ 1

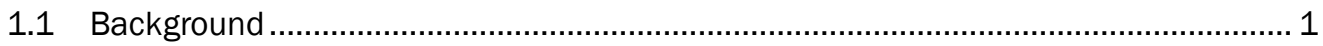

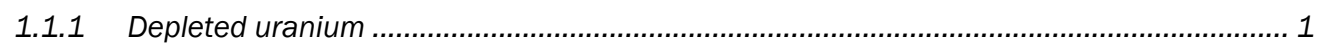

1.1.2 Speciation of uranium and depleted uranium ............................................................... 1

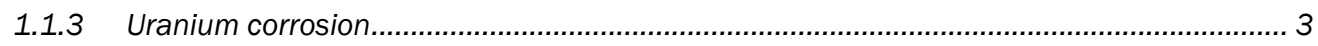

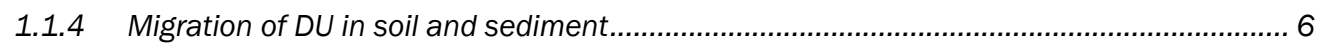

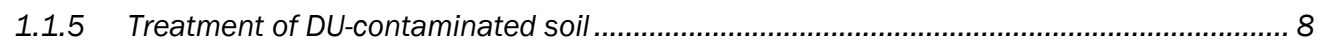

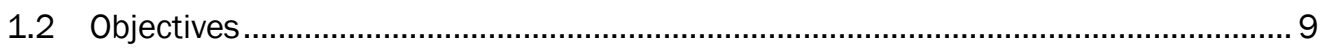

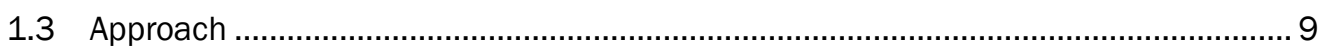

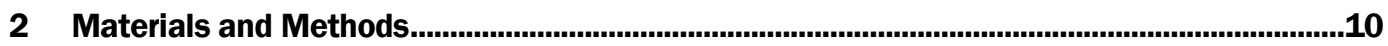

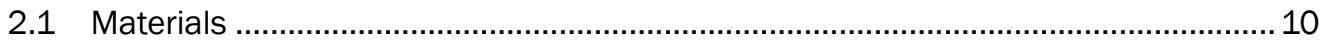

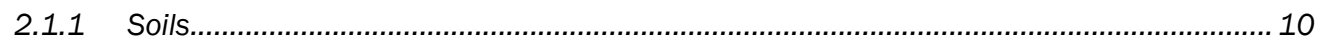

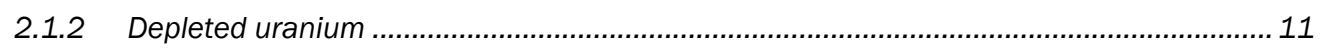

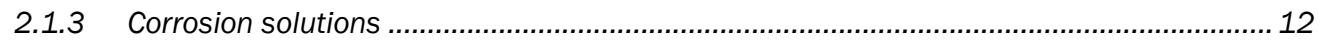

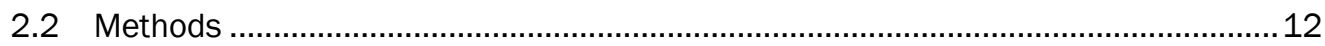

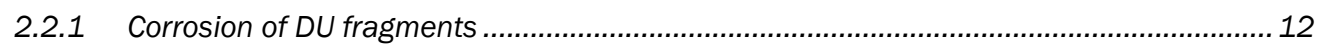

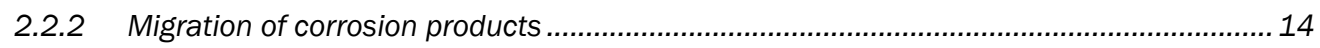

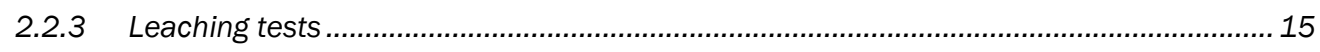

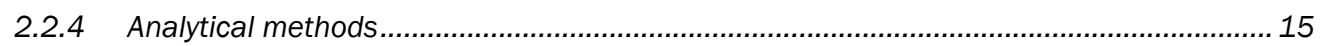

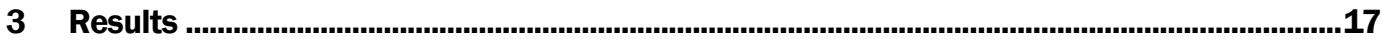

3.1 Corrosion of DU fragments ...................................................................... 17

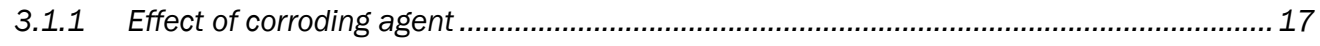

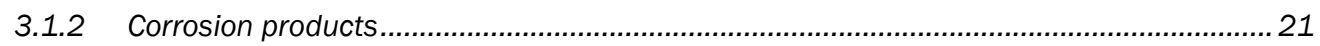

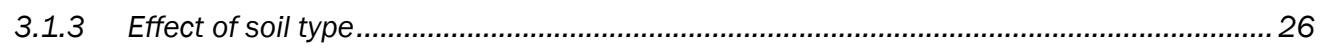

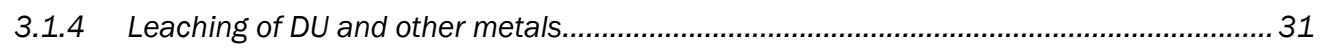

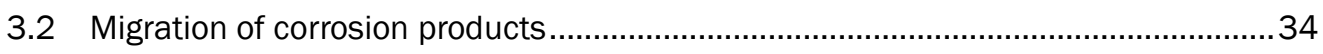

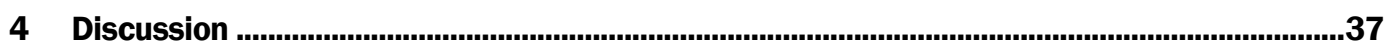

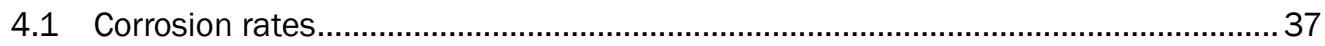

4.2 Interactions with corrosion products .................................................................. 37

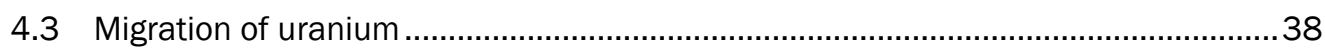

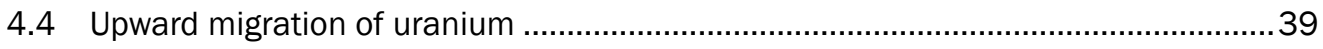

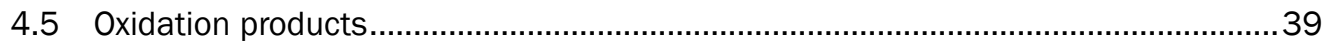

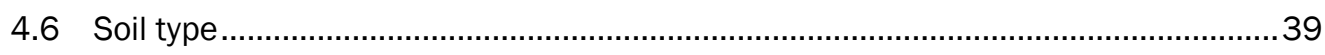

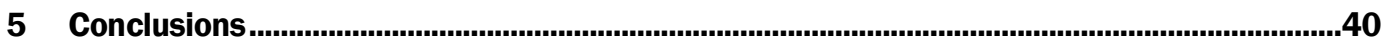

References .................................................................................................................................42

\section{Report Documentation Page}




\section{Figures and Tables}

\section{Figures}

1 Depleted uranium coupon received from Aerojet (Camden, AR)

2 Corrosion products in sand surrounding the fragments of the penetrator rod exposed to salt solution for 14 days (two wet-dry cycles)

3 Close-up view of colored DU corrosion products in sand surrounding the fragment of the penetrator rod exposed to salt solution for 14 days (two wet-dry cycles)

4 Photographs of corrosion on a DU solid exposed to either (A) distilled water (DI) or $(B)$ salt solution for 28 days.......................................................................................19

5 Comparison of final soil pH from pre-corrosion testing ..........................................................21

6 Stereomicrograph of cleaned DU solid fragments demonstrating corrosion produced by exposure to $(A)$ distilled water, $(B)$ salt solution, and $(C)$ acid solution...........22

7 Scanning electron micrograph (SEM) of coupons that underwent corrosion: $(A) \mathrm{DI}$ water and $(B)$ salt solution ................................................................................................2

8 Comparison of change in soil $\mathrm{pH}$ before and after depleted uranium corrosion

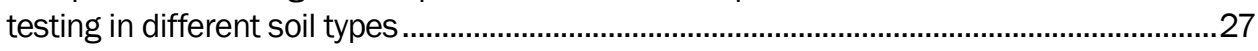

9 Uranium concentration $\left(\mathrm{mg} \mathrm{kg}^{-1}\right)$ in each soil type at the conclusion of the 28day wet-dry corrosion test .............................................................................................28

10 Soil pH by depth in column study of DU migration .......................................................34

\section{Tables}

1 Comparison of uranium solubilities (per Gorman-Lewis et al. 2008) .................................... 2

2 Physical characterization of soils ......................................................................................10

3 Initial metal concentrations ( $\mathrm{mg} \mathrm{kg}^{-1}$ ) of test and control soils (avg $\pm \mathrm{stdev}, n=$ 5). Uranium, the metal of concern for this study, is highlighted in gray......

4 Average post-corrosion metal concentrations in sand $\left(\mathrm{mg} \mathrm{kg}^{-1}, n=5\right)$ after 14 days with corrosive agents..

5 Comparison of loss of corrosion product over 28 days under neutral, acid, and salt conditions in Sand .

6 Uranium concentration ( $\mathrm{mg} \mathrm{L}^{-1}$ ) following DDI S\&S leach testing of sand with DU-

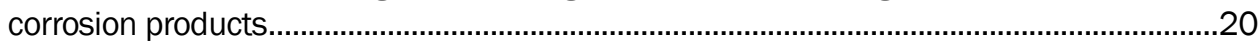

7 Mass loss from the DU penetrator rod fragment over time due to corrosion influenced by distilled water or salt solution in the Sand soil type...

8 Masses of oxidation products removed from the corroded DU penetrator rod fragments in the Sand soil type.

9 Mass percent of selected spectra obtained from backscatter analysis of fragments of a DU penetrator rod corroded using DI water ...

10 Mass percent of selected spectra obtained from backscatter analysis of fragments of a DU penetrator rod corroded using a salt solution ..........................................26

11 Comparison of pre- and post-corrosion metal concentrations for five soil types ................29 
12 Relationship between independent variables of soil type and increase in uranium concentration during corrosion studies..............................................................30

13 Results of multiple linear regression analysis of independent soil variables on

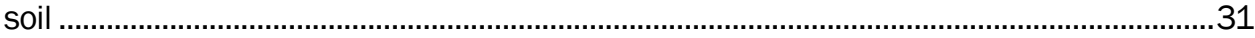

14 Metal concentrations $\left(\mathrm{mg} \mathrm{L}^{-1}\right)$ in leachate produced by the DDI S\&S leach test performed on pre-and post-corrosion testing soils ..............................................................32

15 Metal concentrations in leachate produced by the TCLP leach test performed on post-corrosion testing soils

16 Metal concentrations in leachate produced by the SPLP leach test performed on

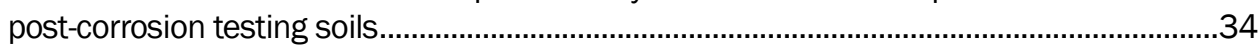

17 Metal concentration $\left(\mathrm{mg} \mathrm{kg}^{-1}\right.$ ) by depth of post-leaching column sand ............................35

18 Post-migration uranium concentrations by depth in leachate using the DDI S\&S

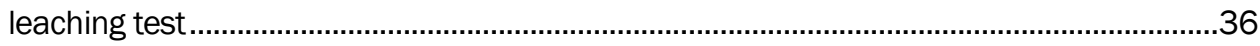

19 Post-migration uranium concentrations by depth in leachate using the TCLP ...................36 


\section{Preface}

This report describes work conducted for the U.S. Army Corps of Engineers through the Engineer Research and Development Center (ERDC), Environmental Laboratory (EL), Environmental Quality/Installations (EQ/I) Research Program, under "Depleted Uranium (DU) Clearance from DOD Ranges." The work was funded under the Department of Defense Appropriations Act Program Element 0603728A to develop innovative and cost-effective remediation solutions for sites contaminated with DU. This report details a study of corrosion and transport of metallic, zero-valent depleted uranium in soil under controlled laboratory conditions. The EQ/I Program was under the direction of Dr. Elizabeth Ferguson.

The work was performed by the Environmental Engineering Branch (CEERD-EPE) of the Environmental Processes and Engineering Division (CEERD-EP), U.S. Army Engineer Research and Development Center, Environmental Laboratory (ERDC-EL); the Concrete and Materials Branch (CEERD-GMC) of the Engineering Systems and Materials Division (CEERD-GM), ERDC Geotechnical and Structures Laboratory (GSL); and Applied Research Associates, Inc. At the time of publication, Dr. W. Andy Martin was Chief, CEERD-EPE; Mr. Warren Lorenz was Chief, CEERDEP; Dr. Elizabeth Ferguson was the Lead Technical Director for EQ/I, and Mr. John Ballard served as the Program Manager for the Depleted Uranium program. The Deputy Director of ERDC-EL was Dr. Jack Davis, and the Director was Dr. Ilker Adiguzel. The Deputy Director of ERDC-GSL was Dr. William P. Grogan, and the Director was Mr. Bartley P. Durst.

Ms. Deborah Felt and Mr. Christopher Griggs (CEERD-EPE) provided inhouse reviews for this report. We also acknowledge support from personnel of the Yuma Proving Ground for their assistance during this project.

COL Bryan S. Green was the Commander of ERDC, and Dr. David W. Pittman was the Director. 


\section{Acronyms and Abbreviations}

ARDEC

ASTM

BCR

CEC

CREAMS

DDI S\&S

DI

DU

EDS

EL

EPIC

EQ/I

ERDC

GSL

HSPF

ICET

ICP-AES

LLW

MSU

$\mathrm{NaCl}$

ND

NU
Armaments Research, Development and Engineering Center

American Society of Testing and Materials

Community Bureau of Reference

Cation Exchange Capacity

Chemical Runoff and Erosion from Agricultural Management Systems

Distilled Deionized Suspend and Settle

deionized

Depleted Uranium

Energy Dispersive X-ray Spectrophotometry

Environmental Laboratory

Erosion-Productivity Impact Calculator

Environmental Quality/Installations

Engineer Research and Development Center

Geotechnical and Structures Laboratory

Hydrological Simulation Program-FORTRAN

Institute for Clean Energy Technology

Inductively Coupled Plasma Atomic Emission Spectrophotometry

Low Level [Radioactive] Waste

Mississippi State University

Sodium Chloride (Salt)

Nondetect

Natural Uranium 


$\begin{array}{ll}\text { OP } & \text { Oxidation Product } \\ \text { SEM } & \text { Scanning Electron Microscope } \\ \text { SPLP } & \text { Synthetic Precipitation Leaching Procedure } \\ \text { stdev } & \text { Standard Deviation } \\ \text { TCLP } & \text { Toxicity Characteristic Leaching Procedure } \\ \text { TOC } & \text { Total Organic Carbon } \\ \text { U } & \text { Uranium } \\ \text { US EPA } & \text { United States Environmental Protection Agency } \\ \text { USACE } & \text { United States Army Corps of Engineers } \\ \text { USCS } & \text { Unified Soil Classification System } \\ \text { VIF } & \text { Variance Inflation Factor } \\ \text { WHC } & \text { Water Holding Capacity }\end{array}$




\section{Introduction}

\subsection{Background}

\subsubsection{Depleted uranium}

Natural uranium (NU) is about $99.27 \% \mathrm{U}-238,0.72 \% \mathrm{U}-235$, and $0.0055 \%$ $\mathrm{U}-234$. The enrichment of fissionable U-235 is accomplished by separating the isotopes of $\mathrm{NU}$ by mass. The remaining byproduct of enrichment is $\mathrm{U}-$ 238, which contains less than one third as much U-235 and U-234 as NU. This U-238 byproduct of enrichment is commonly called depleted uranium (DU). Because U-234 accounts for about half the radioactivity of NU, the external radiation dose from DU is about $60 \%$ of that from the same mass of NU (United States Environmental Protection Agency [U.S. EPA] 2006; McClain and Miller 2007).

DU is useful for its high density of $19.1 \mathrm{~g} / \mathrm{cm}^{3}$ (Craft et al. 2004). Civilian uses of DU include counterweights in aircraft, radiation shielding in medical radiation therapy and industrial radiography equipment, and containers used to transport other radioactive materials (Betti 2003). Military uses include defensive armor plating and munitions; DU penetrators are highly effective against armored vehicles and targets (Keele et al. 1989). Additionally, while DU items are no longer used in routine military training, the Davy Crockett training round is a legacy source of DU on Army ranges. Most DU use in the U.S. is at weapons testing facilities and proving grounds (Ward and Stevens 1994).

\subsubsection{Speciation of uranium and depleted uranium}

Uranium can be found in the environment in several oxidation states, including ${ }^{+} 3,{ }^{+} 4,{ }^{+} 5$, and ${ }^{+} 6$ (Ribera et al. 1996) and zero valent for DU metal. The +4 and +6 are the most common states. Generally, reduced forms are less mobile than the oxidized species.

Like arsenic and aluminum, $\mathrm{U}$ tends to exist in anionic forms, particularly at $\mathrm{pH}>7$ (Rout et al. 2015). Because most surfaces are slightly negatively charged, this tends to result in more mobile species. Uranium also frequently forms hydrates, incorporating water into its structure (Christ and 
Clark 1960; Tamasi et al. 2015). This results in density changes and swelling. The water can also make the $\mathrm{U}$ more reactive to further corrosion and other chemical reactions.

Table 1 compares solubilities of selected U mineral species. Differences in solubility can effect mobility (Gorman-Lewis et al. 2008). For example, the uranyl tricarbonate forms tend to be stable but can be dissolved and released under changing environmental conditions such as change in $\mathrm{pH}$ (Golovich et al. 2011). Silicate and phosphate forms, on the other hand, are stable; and U bound in these forms is less likely to migrate (Runde et al. 2002). In fact, reaction with phosphate (in the form of Apatite II) has been developed as a potential remediation method for $\mathrm{U}$ in groundwater (Conca et al. 2002).

Table 1. Comparison of uranium solubilities (per Gorman-Lewis et al. 2008).

\begin{tabular}{|l|c|c|}
\hline \multicolumn{1}{|c|}{ Species and example compounds } & Formula & Ig $K_{\text {sp }}$ \\
\hline Uranyl carbonates (Rutherfordine) & $\mathrm{UO}_{2} \mathrm{CO}_{3}$ & -13.89 \\
\hline Uranyl oxide (Metaschoepite) & $\mathrm{UO}_{3} * \mathrm{H}_{2} \mathrm{O}$ & 5.52 \\
\hline Uranyl oxide (Becquerelite) & $\mathrm{Ca}\left(\mathrm{UO}_{2}\right)_{6} \mathrm{O}_{4}(\mathrm{OH})_{6} * 8\left(\mathrm{H}_{2} \mathrm{O}\right)$ & 41.2 \\
\hline Uranyl silicate (Soddyite) & $\left(\mathrm{UO}_{2}\right)_{2} \mathrm{SiO}_{4} * 2 \mathrm{H}_{2} \mathrm{O}$ & 6.43 \\
\hline Uranyl phosphate (Chernikovite) & $\left(\mathrm{H}_{3} \mathrm{O}\right)_{2}\left(\mathrm{UO}_{2}\right)_{2}\left(\mathrm{PO}_{4}\right)_{2} * 6 \mathrm{H}_{2} \mathrm{O}$ & -22.73 \\
\hline Uranyl sulfate (Zippeite) & $\mathrm{K}_{4}\left(\mathrm{UO}_{2}\right)_{6}\left(\mathrm{SO}_{4}\right)_{3}(\mathrm{OH})_{10} * 4 \mathrm{H}_{2} \mathrm{O}$ & -146.1 \\
\hline
\end{tabular}

Uranium tends to sorb with reduced or partially oxidized metals, which can affect its mobility (Murphy et al. 1999). This phenomenon has been investigated as an efficient means to remove $\mathrm{U}$ from solutions by adsorbing it to elemental iron (Noubactep et al. 2006) or nanoporous aluminum oxide (Jung et al. 2012). Uranium can also complex with organic materials. Bernhard et al. (1998) conducted thermodynamic modeling calculations relating $\mathrm{U}$ complexation in mining-related waters. The authors determined that complexation can play a key role in migration and can affect the movement of the U in soil and groundwater. Lenhart et al. (2000) found that $\mathrm{U}$ as $\mathrm{U}(\mathrm{VI})$ readily binds with citric, humic, and fulvic acids. Uranium interactions with organic enzymes have also been documented. This interaction resulted in precipitation of dissolved U (Gorby and Lovely 1992). Strong adsorption with plant material has been identified and has been proposed as a phytoremediation method for U-contaminated water (Bhainsa and D'Souza 2001; Butler et al. 2016; Dushenkov et al. 1997). 
Crancon and van der Lee (2003) found that U(VI) could complex with humic matter on the soil, resulting in increased sorption at lower $\mathrm{pH}$. However, organic matter in the pore water resulted in decreased sorption and greater solubilized U. Bednar et al. (2007) also studied interactions of U oxides with organic material. Adding organic material as humic acid to a low-organic soil decreased soil adsorption of $\mathrm{U}$, supporting the findings of Crancon and van der Lee (2003). The study concluded that the humic acid competed with the $\mathrm{U}$ for adsorption sites on the soil, reducing $\mathrm{U}$ adsorption. This mechanism has been proposed to increase U bioavailability for uptake by phytoremediation (Huang et al. 1998).

\subsubsection{Uranium corrosion}

\subsubsection{Oxidation of $D U$}

The specific gravity of DU is $19.1 \mathrm{~g} / \mathrm{cm}^{3}$. This high density makes it relatively difficult for particles to migrate long distances. Although metallic $\mathrm{U}$ is essentially immobile, corrosion reactions with air and water can yield oxidized products, such as schoepite and metaschoepite (hydrated U[VI] oxides) (Chen and Yiacoumi 2002). Other minerals have also been identified as products of $U$ corrosion in soil, including becquerelite, fourmuilerite, and sodium zippeite, among other trace phases (Buck et al. 2004). These minerals have lower densities than metallic DU. For example, the specific gravity of schoepite is $4.90 \mathrm{gm} / \mathrm{cm}^{3}$. The schoepite and other $\mathrm{U}$ minerals can dissolve to soluble $\mathrm{U}(\mathrm{VI})$ as $\mathrm{UO}_{2}{ }^{2+}$, which could enhance DU migration (Chen and Yiacoumi 2002; Senko et al. 2002). Also, complexation of $\mathrm{UO}_{2}{ }^{2+}$ with natural ligands (organic and inorganic) and absorption on soil will further alter mobility, depending on how these secondary compounds interact with soil (Abdelouas et al. 1998; Elless and Lee 1998).

\subsubsection{Relevant corrosion studies from nuclear fuel rod uranium}

Much of the background for the corrosion oxidation of $\mathrm{U}$ has come from studies involving long-term disposal/isolation of spent nuclear rods and studies simulating long-term exposure of spent $\mathrm{U}$ oxides (primarily $\mathrm{UO}_{2}$ ) to groundwater. Abdelouas et al. (1998), as seen in Equation (1), showed the oxidation of $\mathrm{UO}_{2}$ (uraninite) as

$$
2 \mathrm{UO}_{2}+4 \mathrm{H}^{+}+\mathrm{O}_{2}=2 \mathrm{UO}_{2}^{2+}+2 \mathrm{H}_{2} \mathrm{O} \text {. }
$$


This reaction is interesting in two aspects. First, it indicates that the reaction would be enhanced by $\mathrm{H}^{+}$, that is, by lower $\mathrm{pH}$. Second, the reaction generates water, which can react with the $\mathrm{U}$ species to cause swelling.

Wronkiewicz et al. (1992) conducted studies on corrosion of $\mathrm{UO}_{2}$ when exposed to oxygenated groundwater at an elevated temperature $\left(90^{\circ} \mathrm{C}\right)$. Under these conditions, they found rapid oxidation of the $\mathrm{U}$ to uraninite, with measureable U loss detected within 8 weeks. Uraninite was then steadily converted to schoepite. Loss continued for about 2 years, at which time more stable uranyl silicates (i.e., uranophane, boltwoodite, and sklodowskite) phases formed.

\subsubsection{Bench-scale evaluation of corrosion and oxidation of DU}

Handley-Sidhu et al. (2009b) conducted laboratory studies to evaluate corrosion of buried fragments of DU. Schoepite, and metaschoepite are the most common corrosion products although uraninite $\left(\mathrm{UO}_{2}\right)$ and uranyl $\left(\mathrm{UO}_{2}\right)^{2+}$ are also common (Handley-Sidhu et al. 2010). Under near-fieldcapacity water conditions (Handley-Sidhu et al. 2009b), corrosion occurred at a rate of $0.49 \pm 0.06 \mathrm{~g} \mathrm{~cm}^{-2} \mathrm{yr}^{-1}$, and the primary corrosion product was metaschoepite. Rates slowed substantially in waterlogged conditions to $0.01 \pm 0.02 \mathrm{~g} \mathrm{~cm}^{-2} \mathrm{yr}^{-1}$, presumably because of oxygen limitation. Anaerobic conditions completely stopped oxidation. The corrosion process itself changed the soil redox conditions and affected the surrounding microbial community.

Microcosm studies using dune sand to simulate desert environments (Handley-Sidhu et al. 2009c), under field moisture conditions, reported that DU was corroded to metaschoepite at a rate of $0.10 \pm 0.0012 \mathrm{~g} \mathrm{~cm}^{-2}$ $\mathrm{yr}^{-1}$. The metaschoepite easily detached from the penetrator and became distributed in the sand. Corrosion of the DU affected the geochemical environment, stimulating nitrate and iron reduction. The movement of metaschoepite in a sand column was governed by its interactions with the sand itself. Modelling studies suggested that $U$ release from metaschoepite was governed by a slow desorbing surface species.

Schimmack et al. (2007) conducted a three-year mesocosm study on corrosion and leaching of DU munitions (masses ranging from $145 \mathrm{~g}$ to $264 \mathrm{~g}$ ) using buried columns with $3.3 \mathrm{~kg}$ cores (dry soil mass) that were irrigated 
weekly. On average, each DU munition lost $14.5 \mathrm{~g}$ over the three-year study, or about $7 \%$ of its mass. Corrosion increased by a factor of more than 100 after the first year, suggesting that initiation of the corrosion was a key step, followed by the increase in reactive surface area. Uranium species found in the leachate were hydroxyl and carbonate forms while those found in the soil were mostly phosphate forms.

\subsubsection{Field-scale evaluation of DU corrosion}

Baltz (2000) conducted a corrosion study at the Yuma Proving Ground in Arizona. This consisted of creating a DU "garden" with $1 \mathrm{~m}$ long penetrator rods emplaced into the soil, with half of the rod buried in the soil and the upper half exposed to the atmosphere. The study found no corrosion of either section in 250 days of exposure. More recent studies conducted by New Mexico Tech with assistance from the U.S. Army Engineer Research and Development Center, Environmental Laboratory (ERDC-EL), have used a DU garden with penetrator rods (fired and unfired) buried at various depths and left for several years. The penetrator rods can vary substantially in the amount of corrosion found, ranging from slight discoloration on the penetrator to extreme corrosion with a large "bloom" of yellow oxidation product. Samples from this DU garden site are included in other studies conducted as part of the ERDC-EL DU program (Larson et al. 2009, 2012).

Buck et al. (2004) also studied U oxidation products in a soil in the southwestern United States that had DU weathering for 22 years. Schoepite and metaschoepite were, again, the primary corrosion products. These were found primarily as silica cemented, mixed schoepite-metaschoepite/clay/ silt aggregates and as schoepite-metaschoepite-only aggregates. They were also found as coatings on soil grains, but this was relatively rare. These aggregates were relatively immobile. Johnson et al. (2004) also studied DU penetrator rods in alkaline desert soils weathered for 22 years. The authors reported corrosion products on the soil surface and found evidence of subsurface migration. The subsurface products showed evidence of reprecipitation and sorption on soil particles. DU distribution in the soil varied greatly, but some correlations were found with clay content $\left(R^{2}=0.55\right)$ and $\mathrm{pH}\left(R^{2}=0.73\right)$. Near-surface DU was easily dissolved with a weak acid solution (25\% acetic acid for 2 hours). However, DU found several centimeters in depth below the ground surface formed insoluble aggregates 
with silicate minerals, requiring strong acids to achieve leaching. These silicates seemed to limit vertical migration of the DU.

Mellini and Riccobono (2005) studied a single weathered DU penetrator rod collected from the field after about a 2-year exposure in a concrete slab. They found black and yellow oxidation products. X-ray diffraction identified the black product as uraninite $\left(\mathrm{UO}_{2}\right)$ with possibly more oxidized forms $\left(\mathrm{U}_{3} \mathrm{O}_{8}\right)$. The yellow material was determined to be largely amorphous and appeared to contain schoepite $\left(\mathrm{UO}_{3}-2 \mathrm{H}_{2} \mathrm{O}\right)$. Their findings indicated that the yellow material was derived from the black oxidation product and is further oxidized. The oxidation products showed evidence of leaching and migration away from the rod.

Handley-Sidhu et al. (2009a) studied the corrosion and fate of DU penetrator rods in estuarine sediment that was saline and frequently anaerobic. Very slow corrosion rates of $0.056 \pm 0.006 \mathrm{~g} \mathrm{~cm}^{-2} \mathrm{y}^{-1}$ were found in suboxic conditions, as predicted by the laboratory experiments. As the DU corroded, the redox conditions were further lowered, and microbial diversity decreased.

\subsubsection{Migration of DU in soil and sediment}

Modeling studies have investigated the mobility of $U$ and other related radioisotopes in soils (Barnett et al. 2000; Bradbury and Baeyens 2005; Dang et al. 2018; Du et al. 2017; Larson et al. 2004). However, the focus of these studies has been primarily on U(VI), not DU. Murphy and Shock (1999) found that $U$ is common in surface and near-surface waters where ores or waste materials are present. Burns et al. (1991) reported that leaching was the primary migration mechanism in sloping soil (catena) of northern Louisiana, far exceeding overland flow and subsurface through flow. Kaplan and Serkiz (2001), studying sorption of U on sediments, reported a wide range of distribution coefficients ranging from 170 to $6493 \mathrm{~mL} \mathrm{~g}^{-1}$, depending on the species of $U$ and oxidation state. Honeyman and Ranville (2002) reported that movement of colloid-associated metals, including $\mathrm{U}$, in soil pore water was minimal. Movement of dissolved U was slow, with retardation factors of 1300 to 3000 .

Johnson et al. (2006) modeled DU transport in a desert ecosystem and determined that DU movement is minimal under these arid conditions. The 
U.S. EPA (2006) review of DU mentions the effect of $\mathrm{pH}$, organic compounds, redox status, ligand concentration, and aluminum- and iron-oxide mineral concentrations as effecting DU migration in the environment. Information on the effect of the presence of organic colloids on DU migration has been mixed. Oliver et al. (2008a) conducted a study evaluating the mobility and bioavailability of DU along a $200 \mathrm{~m}$ firing line in the United Kingdom. The studies found that DU was associated and migrated with organic colloids in the soil pore water. Crancon et al. (2010) and Harguindeguy et al. (2013) have studied the transport of surficially deposited DU in soils. They found migration of up to $20 \mathrm{~cm}$ after "numerous" years of exposure. Soil retention appeared to be controlled by humic and clay deposits in the soil. Both studies reported the effect of colloids on the migration of DU. They determined that DU is weakly bound to soil aggregates and is more mobile than NU.

In another study using field-contaminated soil, Oliver et al. (2008b) used Community Bureau of Reference (BCR) sequential extractions to study DU distribution and partitioning from soils collected from test ranges in the United Kingdom. The BCR methodology consists of four sequential extractions: the first targets acid-extractable constituents; the second focuses on reducible constituents; the third extraction removes oxidizable materials; and the last is the residual fraction, which includes the metals (Larner et al. 2006). Oliver et al. (2008b) reported that over 50\% of $U$ was retained with the soil organic matter in the oxidizable fraction. As U migrated away from the source zone, greater concentrations were sequestered in the exchangeable fraction. Larson et al. (2009), using the sequential extraction system of Tessier et al. (1979), also reported greater concentrations of U in the organic matter fraction, shifting to the carbonate fraction at depths further from the source zone.

Testing with DU munitions has been conducted in the field at the Yuma Proving Ground (Ward and Stevens 1994) where the firing had been conducted in an area that affects a $10 \mathrm{~km}^{2}$ wash. Rael (1997) used three models to evaluate the mobility of DU at the Yuma Proving Ground-Chemical Runoff and Erosion from Agricultural Management Systems (CREAMS); Hydrological Simulation Program-FORTRAN (HSPF); and ErosionProductivity Impact Calculator (EPIC)- which focus on erosion, runoff, and contaminant support. These studies have concluded that the most 
likely means for DU to migrate off the ranges is through transport in runoff-water sediment, either as very small DU particles or as corrosion products adsorbed onto sediment particles. Chen and Yiacoumi (2002) suggested that migration of DU into soil surrounding a penetrator rod was slow due to the relatively slow oxidation of DU from the rod. Rael (1997) also concluded that a major drawback was that the models did not account for chemical transformations of the DU metal to oxidized products, particularly schoepite. Information on the behavior of these oxidation products has lately been more available.

In reviewing various studies of $U$ and DU mobility, it is clear that DU mobility is strongly tied to its corrosion. Mobility is essentially nonexistent without corrosion.

\subsubsection{Treatment of DU-contaminated soil}

Remediation of DU from soils has not been common. Standard practice for catchbox cleanouts is to excavate the DU-contaminated sand and dispose of it in a low-level radioactive waste (LLW) facility*. Recovered penetrator rods can also be disposed of in LLW facilities.

Larson et al. (2009, 2012) evaluated physical separation approaches for removing DU from soil and catchbox sand at both the pilot and field scale. These studies indicated that at least $50 \%$ of the DU tends to be in large metallic chunks or in aggregated corrosion product that can be removed by screening methods. However, the remaining portion, the contaminated soil fines, are difficult to remediate by physical separation. Other soil remediation options include acid leaching processes (Gavrilescu et al. 2009; Unz et al. 2018), which could result in formation of additional oxidized material if metallic DU remains in the soil. These leaching processes have been determined to be capable of removing at least $90 \%$ of the DU oxides from the soil fines. Cost modeling showed that the cost drivers were the soil volume to be remediated, the percentage of DU, and the size of the area to be remediated. Comparing various treatment options, the cost model showed the lowest cost for remediation to be selective excavation of the contaminated soil followed by physical separation of that soil and

\footnotetext{
* M. Svoboda, health physicist, personal communication, 2005. Yuma, AZ: Yuma Proving Ground Safety Office.
} 
chemical treatment of the residual soil fines (Farr et al. 2016; Walters et al. 2014).

To date, the authors of this report are aware of only one completed DU soil remediation project. This project involved removal of DU-contaminated soils (from Davy Crockett firings) at the Schoefield Barracks in Oahu, Hawaii, from 2006 to 2008. In this case, the soil was excavated, screened for radioactive components, and sent to an LLW for disposal ${ }^{*}$ (G. Kompf, U.S. Army Radiation Safety Officer, pers. comm.).

\subsection{Objectives}

While fate and migration of $\mathrm{U}$ species is generally well understood, the most uncertain aspect is transport from the corrosive release of oxidation products. As part of the research effort to understand movement of DU in the environment, this study focuses on short-term (time frame of weeks) corrosion of DU under differing environmental conditions to characterize rates and U species formed. The work was funded under the Department of Defense Appropriations Act to develop innovative and cost-effective remediation solutions for sites contaminated with DU.

\subsection{Approach}

This study used a bench-scale approach. Five well-characterized soils were treated with alternating wet-dry cycles to simulate rapid aging of DU. The DU was supplied by either fired penetrator fragments or standard coupons used as aircraft weights. The moisture for aging was either distilled water, a mild acid or a salt solution to simulate different environmental effects on the uranium. Researchers at ERDC used inductively coupled plasma atomic emission spectrophotometry (ICP-AES) to analyze the soil and water samples for uranium, examined penetrator fragments by scanning electron spectrometry and X-ray backscatter analysis for corrosion products, and compared soil leachates. This report compares and discusses the corrosion products of DU under different environmental conditions and transport of those products through sand columns.

* G. Kompf, U.S. Army Radiation Safety Officer, personal communication. Washington, DC. 


\section{Materials and Methods}

\subsection{Materials}

\subsubsection{Soils}

Table 2 summarizes the physical characteristics of the soils used in this study. Classification of the soil samples was done according to American Society of Testing and Materials (ASTM) D2487 (2011). This standard identifies soils based on the laboratory determination of particle size and classifies them as silts, clays, sands, and gravels by using the Unified Soil Classification System (USCS).

The soils used in this study represented a wide range of soil types from largely sand to silt/clay. Yuma Proving Ground was a somewhat coarser Silty Sand. Total organic carbon (TOC) content ranged from 3000 to $20,000 \mathrm{mg} / \mathrm{kg}$, and the cation exchange capacity (CEC) varied from 0.006 to $11 \mathrm{meq} / \mathrm{g}$. Soil $\mathrm{pH}$ varied from 5.03 to 7.99 . The water holding capacity (WHC) ranged from $18.0 \%$ to $27.5 \%$. The sand had the lowest WHC, $18 \%$, whereas soil from Fort Knox, a clay soil, had the highest at $27.49 \%$.

Table 2. Physical characterization of soils.

\begin{tabular}{|c|c|c|c|c|c|}
\hline \multirow[b]{2}{*}{ Parameter } & \multicolumn{5}{|c|}{ Soil } \\
\hline & $\begin{array}{l}\text { Sand } \\
\text { (Control) }\end{array}$ & $\begin{array}{c}\text { Aberdeen Proving } \\
\text { Ground }\end{array}$ & $\begin{array}{l}\text { Yuma Proving } \\
\text { Ground }\end{array}$ & Fort Knox & Fort Polk \\
\hline Classification & Sand & Clay & $\begin{array}{l}\text { Silty Sand } \\
\text { (coarse) }\end{array}$ & Sandy Clay & $\begin{array}{l}\text { Silty Sand } \\
\text { (fine) }\end{array}$ \\
\hline $\mathrm{pH}$ & 7.99 & 7.24 & 7.81 & 5.03 & 6.10 \\
\hline$\%$ Gravel & 0.1 & 2.9 & 16.4 & 2.7 & 0.1 \\
\hline$\%$ Sand & 96.6 & 25.4 & 67.7 & 8.3 & 72.9 \\
\hline$\%$ Fines & 3.3 & 71.7 & 15.9 & 88.9 & 27.0 \\
\hline $\begin{array}{l}\text { Cation exchange } \\
\text { capacity (CEC, meq/g) }\end{array}$ & 0.007 & 0.157 & 0.207 & 11.00 & 8.00 \\
\hline $\begin{array}{l}\text { Anion exchange capacity } \\
\text { (meq/g) }\end{array}$ & 0.005 & 0.015 & 0.023 & 0.025 & 0.013 \\
\hline $\begin{array}{l}\text { Total organic carbon } \\
\text { (TOC, mg/kg) }\end{array}$ & 3000 & 9570 & 11,300 & 20,000 & 14,000 \\
\hline $\begin{array}{l}\text { Water Holding Capacity } \\
\text { (WHC, \%) }\end{array}$ & 18.00 & 25.92 & 22.82 & 27.49 & 25.10 \\
\hline
\end{tabular}


Table 3 summarizes the initial metal concentrations of the test and control soils. Both molybdenum and antimony (unlisted) were initially at nondetect concentrations in all soil types.

Table 3. Initial metal concentrations $\left(\mathrm{mg} \mathrm{kg}^{-1}\right.$ ) of test and control soils (avg \pm stdev, $n=5$ ). Uranium, the metal of concern for this study, is highlighted in gray.

\begin{tabular}{|c|c|c|c|c|c|}
\hline \multirow[b]{2}{*}{ Metal } & \multicolumn{5}{|c|}{ Soil } \\
\hline & $\begin{array}{l}\text { Sand } \\
\text { (Control) }\end{array}$ & Clay & $\begin{array}{c}\text { Silty Sand, } \\
\text { Coarse }\end{array}$ & Sandy Clay & $\begin{array}{l}\text { Silty Sand } \\
\text { (Fine) }\end{array}$ \\
\hline Uranium (U) & ND & $24.44 \pm 0.60$ & $\begin{array}{c}13.44 \pm \\
0.56\end{array}$ & $\begin{array}{c}35.70 \pm \\
1.98\end{array}$ & $9.77 \pm 1.55$ \\
\hline Arsenic & ND & ND & $6.11 \pm 0.29$ & ND & ND \\
\hline Chromium & ND & $19.79 \pm 0.76$ & $\begin{array}{c}11.82 \pm \\
0.78\end{array}$ & $\begin{array}{c}15.95 \pm \\
0.81\end{array}$ & $8.20 \pm 0.30$ \\
\hline Copper & ND & $17.50 \pm 1.14$ & $\begin{array}{c}10.56 \pm \\
0.45\end{array}$ & $8.37 \pm 0.34$ & $9.20 \pm 0.41$ \\
\hline Iron & $960 \pm 59$ & $19,804 \pm 362$ & $10,806 \pm 23$ & $\begin{array}{c}18,483 \pm \\
552\end{array}$ & $5,908 \pm 78$ \\
\hline Lead & ND & $27.88 \pm 6.37$ & $5.37 \pm 0.24$ & $8.86 \pm 1.12$ & $42.81 \pm 1.21$ \\
\hline Manganese & $\begin{array}{c}14.14 \pm \\
1.69\end{array}$ & $488.53 \pm 18.00$ & $\begin{array}{c}238.73 \pm \\
7.94\end{array}$ & $\begin{array}{c}202.63 \pm \\
8.27\end{array}$ & $26.77 \pm 0.66$ \\
\hline Nickel & ND & $17.62 \pm 0.51$ & $\begin{array}{c}13.34 \pm \\
0.68\end{array}$ & $\begin{array}{c}17.33 \pm \\
0.90\end{array}$ & ND \\
\hline Zinc & ND & $45.29 \pm 1.34$ & $31.72 \pm 1.51$ & $\begin{array}{c}64.83 \pm \\
1.37\end{array}$ & $9.00 \pm 1.76$ \\
\hline
\end{tabular}

$\mathrm{ND}=$ nondetect

stdev $=$ standard deviation

\subsubsection{Depleted uranium}

Two sources of zero-valent DU were used. The first source consisted of pieces of DU penetrator rod material with no noticeable oxidation. These were collected from the Yuma Proving Ground by researchers from Mississippi State University-Institute for Clean Energy Technology (MSUICET), Starkville, MS. The fragments were roughly circular in shape and had similar masses (39.5 g, $39.6 \mathrm{~g}$, and $40.4 \mathrm{~g}$ ). The surface areas of the three pieces were $9.54,9.55$, and $9.65 \mathrm{~cm}^{2}$, respectively.

The second DU source was a set of uniform pieces (coupons), obtained from Aerojet (Camden, AR), with an average mass of $187.4 \mathrm{~g}( \pm 0.8 \mathrm{~g})$ 
(Figure 1). Each piece had a diameter of $1.27 \mathrm{~cm}$ and a length of $2.00 \mathrm{~cm}$, giving a surface area of $10.50 \mathrm{~cm}^{2}$. Personnel at the Armaments Research, Development, and Engineering Center (ARDEC) at Picatinny, NJ, aided in acquiring these materials.

Figure 1. Depleted uranium coupon received from Aerojet (Camden, AR).

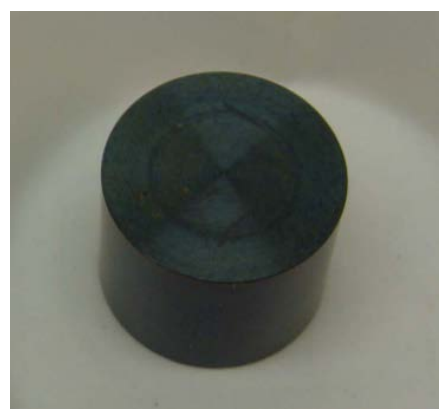

\subsubsection{Corrosion solutions}

Our studies used three types of solutions to affect DU corrosion: a salt solution, an acid solution, and deionized (DI) water. The salt solution consisted of $3.5 \%$ sodium chloride $(\mathrm{NaCl})$ in deionized water. The acidic solution was prepared using the method outline in the Synthetic Precipitate Leaching Procedure (SPLP) in U.S. EPA SW-846 Method 1312 (U.S. EPA 1999). The DI water was prepared by a Barnstead/Thermolyne water system (Thermo Fisher Scientific, USA). All chemicals were reagent grade (Thermo Fisher Scientific, USA).

\subsection{Methods}

\subsubsection{Corrosion of DU fragments}

\subsubsection{Effect of corroding agent}

For this study, researchers performed a series of drying-rewetting experiments, adapted from Xiang et al. (2008), to investigate DU corrosion over time. These experiments used the Sand soil type and compared the corrosion that resulted from different wetting solutions:
1. DI water
2. Acid (SPLP) solution
3. Salt solution $(3.5 \% \mathrm{NaCl})$ 
The experiments were conducted in a radiation laboratory using $400 \mathrm{~mL}$ glass beakers. The beakers were filled with $150 \mathrm{~g}$ of sand, $30 \mathrm{~mL}$ of the appropriate solution, and a fragment of a DU penetrator rod. An initial mass of the beakers and the contents was recorded as was an initial mass of each piece of the penetrator. There were four cycles of rewetting events separated by 6-day drying periods. To ensure total drying of the soils, 3 days of drying at room temperature were followed by 3 days of drying with $250 \mathrm{~W}$ heat lights. Rewetting events were based on the $18 \%$ WHC of the sand. Samples were rewetted by slowly adding solution into the test container with a $60 \mathrm{~mL}$ syringe.

After 14 days, or 2 dry-wet cycles, the DU fragments were removed from one DI-water and one salt-solution experiment. These fragments were used for scanning electron spectrometry and X-ray backscatter analysis of corrosion products. After 28 days, the DU fragments were removed from the remaining sands. A final mass was taken of each DU fragment. Two oxidation products were collected from each fragment; the first oxidation product was removed using a plastic spatula, and the second product was removed using a wire brush. Metals were extracted from the oxidation products and analyzed by using SW-846 Method 3051 (U.S. EPA 1999).

\subsubsection{Effect of soil type}

A second drying-rewetting experiment was set up to investigate corrosion over time using five soil types and deionized water as the corrosion agent. The experimental soil types, described in Table 2, studied were Clay (Aberdeen Proving Ground), Sandy Clay (Fort Knox), Silty Sand 1 (Fort Polk), and Silty Sand 2 (Yuma Proving Ground). Fine construction sand was used as the control. The purpose was to ascertain the contribution of the soil's physical and chemical properties to the observed corrosion of the DU fragments.

The experiment was conducted in a radiation laboratory. Three hundred grams of soil were placed in a $400 \mathrm{~mL}$ glass beaker. There was one replicate per soil. Deionized water was added based on the $18 \%$ WHC of each soil type along with a zero-valent DU penetrator fragment. An initial mass of the beakers and the contents was recorded as was an initial mass of each DU penetrator fragment. The duration of the experiment was 154 days. In 
total, there were 22 dry-wet cycles, each separated by a 6-day drying period: 3 days at room temperature and 3 days under $250 \mathrm{~W}$ heat lights. Rewetting events were based on the WHC of each soil. Samples were rewetted slowly using a $60 \mathrm{~mL}$ syringe.

At the end of the study, DU penetrator pieces were retrieved from the test containers. A final mass was taken of each piece. The corrosion products were removed by spatula and by metal brush to determine the actual amount of material reacted. Soil samples underwent total metal analysis using SW-846 Method 3050 (U.S. EPA 1999) and three leaching tests: the DDI Suspend and Settle (DDI S\&S), the Toxicity Characteristic Leaching Procedure (TCLP), and the SPLP. Section 2.2.3 details the leaching procedures.

\subsubsection{Migration of corrosion products}

The migration test was conducted in the radiation laboratory using a Plexiglas leaching column that was $23 \mathrm{~cm}$ in height by $52.5 \mathrm{~cm}$ wide and with an inner diameter of $15 \mathrm{~cm}$. The bottom of the column consisted of a hole for leachate removal. A paper filter was place at the bottom of the column to prevent sand loss. Sand ( $5.8 \mathrm{~kg}$ ) was added to each column. The coupon was added $6 \mathrm{~mm}$ from the top of the column. Another layer of sand was added up to $2 \mathrm{~mm}$ from the top to cover the coupon. The sand was packed into the column by tapping the top of the column consistently while the sand was slowly poured into place. The column was set on a stand at room temperature for 119 days. Deionized water was applied initially to the column based on the WHC of $18 \%$. Salt solution $(3.5 \% \mathrm{NaCl})$ was added biweekly after two additions of deionized water.

Leachate was collected in a $1000 \mathrm{~mL}$ Nalgene bottle and analyzed for metal concentrations, $\mathrm{pH}$, and oxidation reduction potential. Portions of filtered $(0.45 \mu \mathrm{m})$ and unfiltered leachate samples were refrigerated prior to water analysis for soluble metals extracted using U.S. EPA SW-846 Method 3015 (U.S. EPA 1999).

As the columns were disassembled, sand samples were collected at $1 \mathrm{in}$. $(2.54 \mathrm{~cm})$ intervals. Each sample was analyzed for total metals concentration completed using U.S. EPA SW-846 Method 3050 (U.S. EPA 1999). Each sample was then divided and subjected to one of the three leaching 
tests: the DDI S\&S, the TCLP, and the SPLP. The leachates were also analyzed for metals using the methods described above.

\subsubsection{Leaching tests}

The TCLP was completed following SW-846 Method 1311 (U.S. EPA 1999) to evaluate the leaching potential of the contaminated soils under aggressive leaching conditions. A 1:20 (weight:volume) soil-to-extraction-solution ratio was used. The soil extractions were placed on a tumbler for $18 \pm$ 2 hours. After tumbling, an aliquot of the sample was removed and centrifuged, and then $60 \mathrm{~mL}$ of sample was filtered through a $0.45 \mu \mathrm{m}$ syringe filter and analyzed for metals.

The SPLP test was completed following SW-846 Method 1312 (U.S. EPA 1999). As with the TCLP, a 1:20 (weight:volume) soil-to-extraction-solution ratio was used, and the soil extractions were placed on a tumbler for $18 \pm 2$ hours. After tumbling, an aliquot of the sample was removed and centrifuged, and then $60 \mathrm{~mL}$ of sample was filtered through a $0.45 \mu \mathrm{m}$ syringe filter and analyzed for metals.

The DDI S\&S procedure, a modification of TCLP, is a water-leaching test. The test varies from the TCLP and the SPLP by using a nonaggressive extraction liquid at circumneutral $\mathrm{pH}$ and less shaking time. Subsamples (20 g each) of each soil were weighed into $500 \mathrm{~mL}$ Nalgene bottles, and $400 \mathrm{~mL}$ of deionized water was added to each bottle. The samples were placed on an end-to-end shaker for 1 hour and then permitted to settle for $18 \pm 2$ hours. Samples were centrifuged, as necessary, at 2000 revolutions per minute. Following settling, aliquot specimens were filtered through a $0.45 \mu \mathrm{m}$ syringe filter and analyzed for metals.

\subsubsection{Analytical methods}

Soil pH was measured in accordance with ASTM D4972 (2013) by using an electronic pH meter (Thermo Fisher Scientific FE150 3-in-1 benchtop meter, Thermo Fisher Scientific, USA). TOC was determined using U.S. EPA Method 9060 (1999) on a Shimadzu TOC-V/SSM-5000A according to manufacturer's specifications. CEC was determined using U.S. EPA Method 9081 (1999) (sodium acetate method) according to manufacturer's specifications. The WHC of each soil was determined using the method of Waisner et al. (2011). 
Both liquid and solid samples were analyzed for heavy metals by using ICP-AES on a Perkin-Elmer Optima 4300 dual view (Perkin-Elmer, USA) with a reporting limit of $0.025 \mathrm{mg} \mathrm{L}^{-1}$ for liquids and $5.0 \mathrm{mg} \mathrm{Kg}^{-1}$ for solids.

Chemical data was analyzed using SigmaPlot 12.5 (Systat Software, Inc., Richmond, CA). Numbers of replicates varied and are reported with the experimental results.

Samples were imaged using an FEI Nova NanoSEM 630 field emission environmental scanning electron microscope (SEM). Images were obtained in low-vacuum mode (pressure of 0.1 to 1.0 mbar) to minimize charging and the need for applying conductive coatings for imaging. All images were obtained using a backscatter electron detector to improve phase contrast. In conjunction with SEM imaging, chemical analysis was performed using an integral Bruker AXS energy-dispersive X-ray spectrometer (EDS) system. Point analysis was performed on individual particles as was chemical mapping of elements identified as being present in the specimens based on EDS spectra. 


\section{Results}

\subsection{Corrosion of DU fragments}

\subsubsection{Effect of corroding agent}

A drying-rewetting experiment compared the effects of corrosion over time using distilled water, acid, or a salt solution as the corrosive agent. The DU fragments were tested in sand. Yellow oxidation product was first noticed in the sand media at 14 days. Table 4 reports the metal concentrations found in the sand following immersion of the penetrator fragment for 28 days with different corrosive agents. All corrosion media showed measurable concentrations of U, compared to the control with no DU coupon. Concentration of $U$ was highest in the acid-treated sand, followed by the distilled water treatment, and was lowest in the salt treatment. The sand originally contained measurable concentrations of iron, manganese, and aluminum. After the corrosion experiments, these elements were found in the sand at concentrations comparable to the initial concentration. Small quantities of lead, chromium, and copper were found in the salt corrosion media but not in the DI water or the acid corrosion media.

Table 4. Average post-corrosion metal concentrations in sand $\left(\mathrm{mg} \mathrm{kg}^{-1}, n=5\right)$ after 14 days with corrosive agents.

\begin{tabular}{|l|c|c|c|c|}
\hline \multirow{2}{*}{ Metal } & \multicolumn{4}{|c|}{ Soil } \\
\cline { 2 - 5 } & $\begin{array}{c}\text { DI + No Coupon } \\
\text { (Control) }\end{array}$ & DI + Coupon & Salt + Coupon & SPLP + Coupon \\
\hline Uranium (U) & ND & $210.60 \pm 3.86$ & $4,440.00 \pm 139.73$ & $55.42 \pm 4.04$ \\
\hline Arsenic & ND & ND & ND & ND \\
\hline Chromium & ND & ND & 6.39 & ND \\
\hline Copper & ND & ND & 9.25 & ND \\
\hline Iron & $914.87 \pm 72.00$ & $885.30 \pm 11.92$ & $982.47 \pm 92.30$ & $1,022.67 \pm 19.09$ \\
\hline Lead & ND & ND & 7.24 & ND \\
\hline Manganese & $15.53 \pm 0.47$ & $14.56 \pm 0.16$ & $19.00 \pm 0.46$ & $14.49 \pm 0.51$ \\
\hline Nickel & ND & ND & ND & ND \\
\hline Zinc & ND & ND & ND & ND \\
\hline
\end{tabular}

$\mathrm{ND}=$ nondetect 
Corrosion products of DU have one of two fates; they can either migrate away from the metal source or stay associated with the metal. DU corrosion products, noted at 14 days, could be seen clearly in the sand media after the 28-day experiment, with both black and yellow oxidation products being clearly present (Figures 2 and 3 ).

Figure 2. Corrosion products in sand surrounding the fragments of the penetrator rod exposed to salt solution for 14 days (two wet-dry cycles).

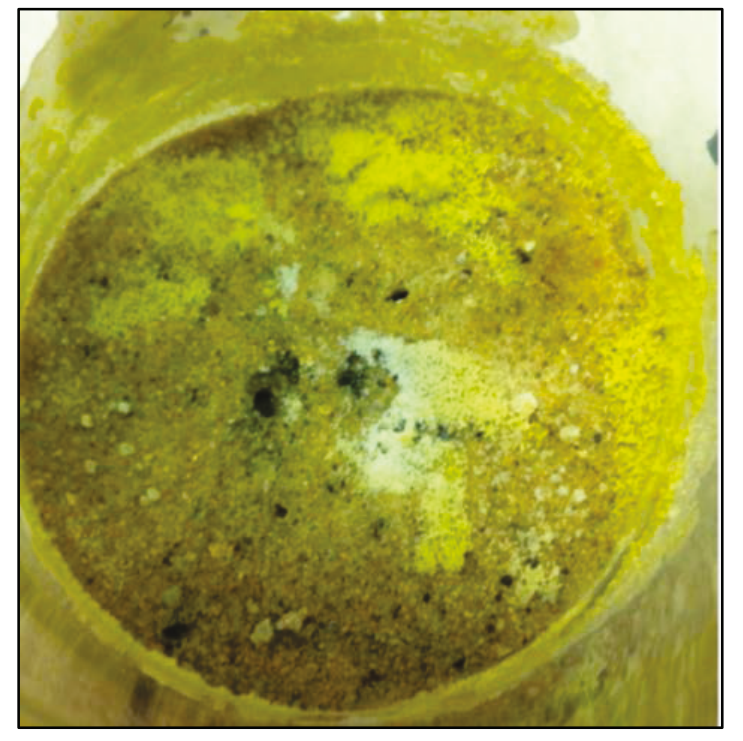

Figure 3. Close-up view of colored DU corrosion products in sand surrounding the fragment of the penetrator rod exposed to salt solution for 14 days (two wet-dry cycles).

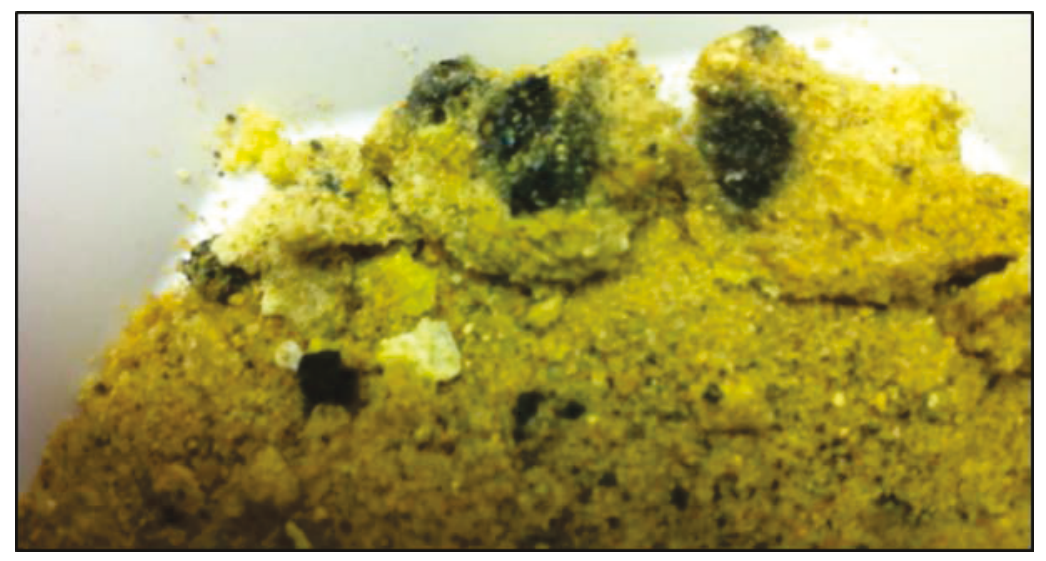

Figure 4 shows fragments containing DU retrieved from the DI water and the salt-solution systems after 28 days of wet-dry cycles. These photo- 
graphs were taken prior to physical efforts to remove the oxidation product from the DU fragment. For both the DI water and salt-solution treatments, yellow oxidation product can be seen clearly on the DU coupon. In addition, for the salt treated coupon, which had more-evident corrosion, sand was observed to be sticking tightly to the penetrator fragment. Following physical removal of the corrosion products, each fragment was reweighed.

Figure 4. Photographs of corrosion on a DU solid exposed to either $(A)$ distilled water (DI) or (B) salt solution for 28 days.

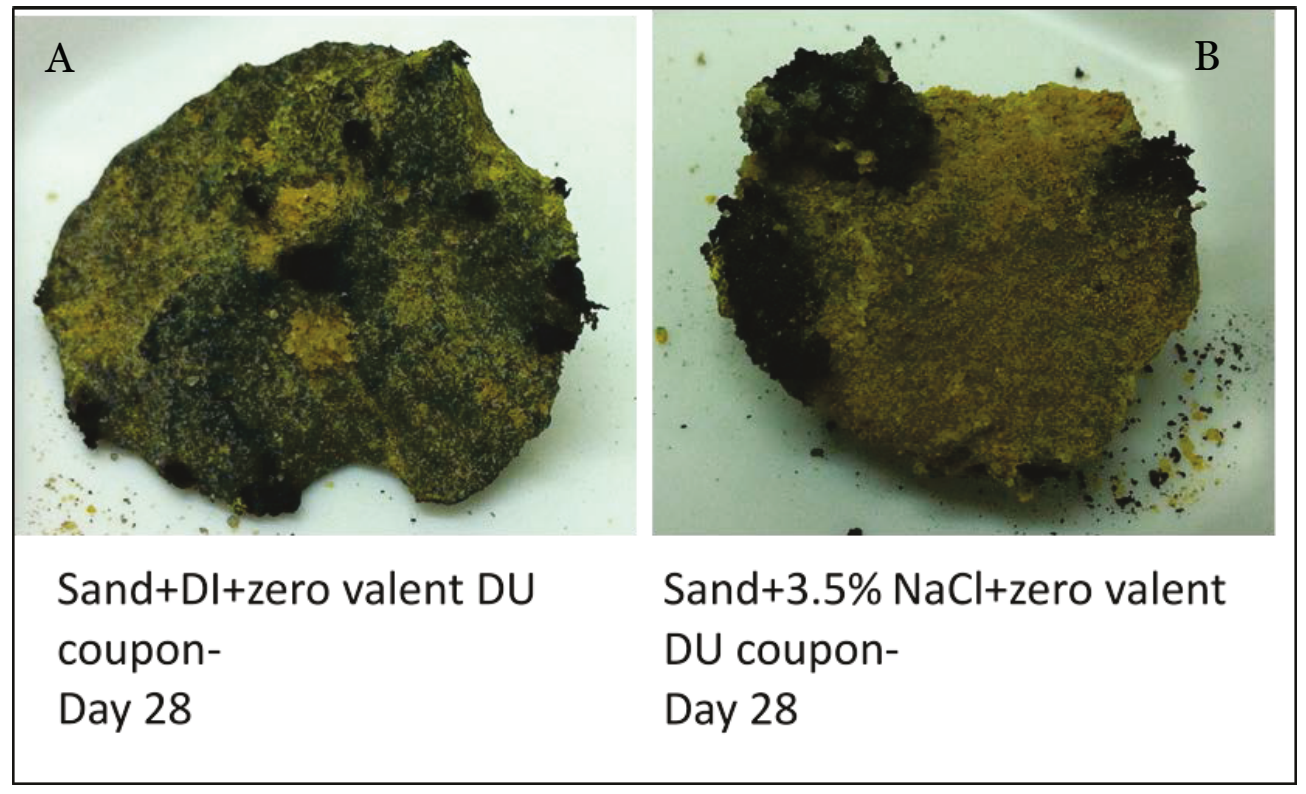

Uranium concentrations in the sand of the DI water corrosion, salt corrosion, and acid corrosion treatments were 210, 4440, and $55 \mathrm{mg} \mathrm{kg}^{-1}$, respectively (Table 5). The control showed nondetectable U concentration (not shown in Table 4). The highest $\mathrm{U}$ concentration in the media did not translate into highest mass loss by corrosion. The least percent mass loss (46\%) was under the salt conditions. The greatest percent loss (83\%) of total mass from the DU fragment was found to be under the acid corrosion conditions. However, the greatest mass loss (highest amount of corrosion) was found to be in the fragment tested under salt corrosion conditions $(1.44 \mathrm{~g})$ while the least mass lost was under the acid conditions (0.01 g). 
Table 5. Comparison of loss of corrosion product over $\mathbf{2 8}$ days under neutral, acid, and salt conditions in Sand.

\begin{tabular}{|l|c|c|c|}
\hline \multirow{2}{*}{\multicolumn{1}{|c|}{ Parameter }} & \multicolumn{3}{|c|}{ Sample in Sand } \\
\cline { 2 - 4 } & DI+ coupon & salt+ coupon & SPLP+ coupon \\
\hline $\begin{array}{l}\text { U concentration in } \\
\text { sand }\left(\mathrm{mg} \mathrm{kg}^{-1}\right)\end{array}$ & $210.60 \pm 3.86$ & $4440.00 \pm 139.73$ & $55.42 \pm 4.04$ \\
\hline Loss from fragment (g) & 0.05 & 1.44 & 0.01 \\
\hline \% loss of total mass & 63 & 46 & 83 \\
\hline
\end{tabular}

Once removed from direct contact with the DU fragment, the corrosion products could either become bound to the sand or be available for movement with water. A mild leaching test was used to suggest the strength of the binding between the corrosion products and the sand matrix. Table 6 compares the results of the DDI S\&S leaching test between corrosion treatments and the control sand. The results of the DDI S\&S extraction indicate that some of the DU corrosion products associated with the sand are miscible with water. Values ranged from $0.41 \mathrm{mg} \mathrm{L}^{-1}$ (for both the DI and acid corrosion solutions) to $19.22 \mathrm{mg} \mathrm{L}^{-1}$ for the salt solution. However, compared to the mass of $U$ in the soil, the amount removed by the DDI S\&S is small, ranging from $0.52 \%$ for the DI solution to $1.15 \%$ for the salt solution to $1.97 \%$ for the acid solution. This indicates that the DU-derived $\mathrm{U}$ in the sand is largely bound to the sand.

Table 6. Uranium concentration ( $\mathrm{mg} \mathrm{L}^{-1}$ ) following DDI S\&S leach testing of sand with DUcorrosion products.

\begin{tabular}{|l|c|c|c|c|}
\hline \multirow{2}{*}{ Parameter } & \multicolumn{3}{|c|}{ Treatment } \\
\cline { 2 - 5 } & $\begin{array}{c}\text { Clean Sand/No } \\
\text { Coupon (Control) }\end{array}$ & DI/Coupon & Salt/Coupon & SPLP/Coupon \\
\hline $\begin{array}{l}\text { Concentration of U } \\
\left(\mathrm{mg} \mathrm{L}^{-1}\right)\end{array}$ & $\mathrm{ND}$ & $0.41 \pm 0.01$ & $19.22 \pm 2.88$ & $0.41 \pm 0.10$ \\
\hline$\%$ mass loss & $0 \%$ & $0.52 \%$ & $1.15 \%$ & $1.97 \%$ \\
\hline
\end{tabular}

The DDI S\&S leach test is also an acceptable means to equilibrate soil for $\mathrm{pH}$ measurement. Figure 5 summarizes $\mathrm{pH}$ measurements associated with the sand used for each corrosion treatment. The initial $\mathrm{pH}$ of the sand was 7.99. After the experiment, the control sand had a pH of 7.83, which was not statistically significant from the initial pH. The DI-water- and acid-exposed treatments had similar $\mathrm{pH}$ (7.46 and 7.47). These were close to the initial $\mathrm{pH}$ but statistically lower. The greatest $\mathrm{pH}$ effect came from the salt 
treatment, which had a final pH of 5.03. Rout et al. (2015), studying the effect of salinity by $\mathrm{NaCl}$ on the mobility of $\mathrm{U}$, reports that increases in ionic strength appear to mobilize U(VI) from soil exchange sites, forcing it into solution.

Figure 5. Comparison of final soil pH from pre-corrosion testing.

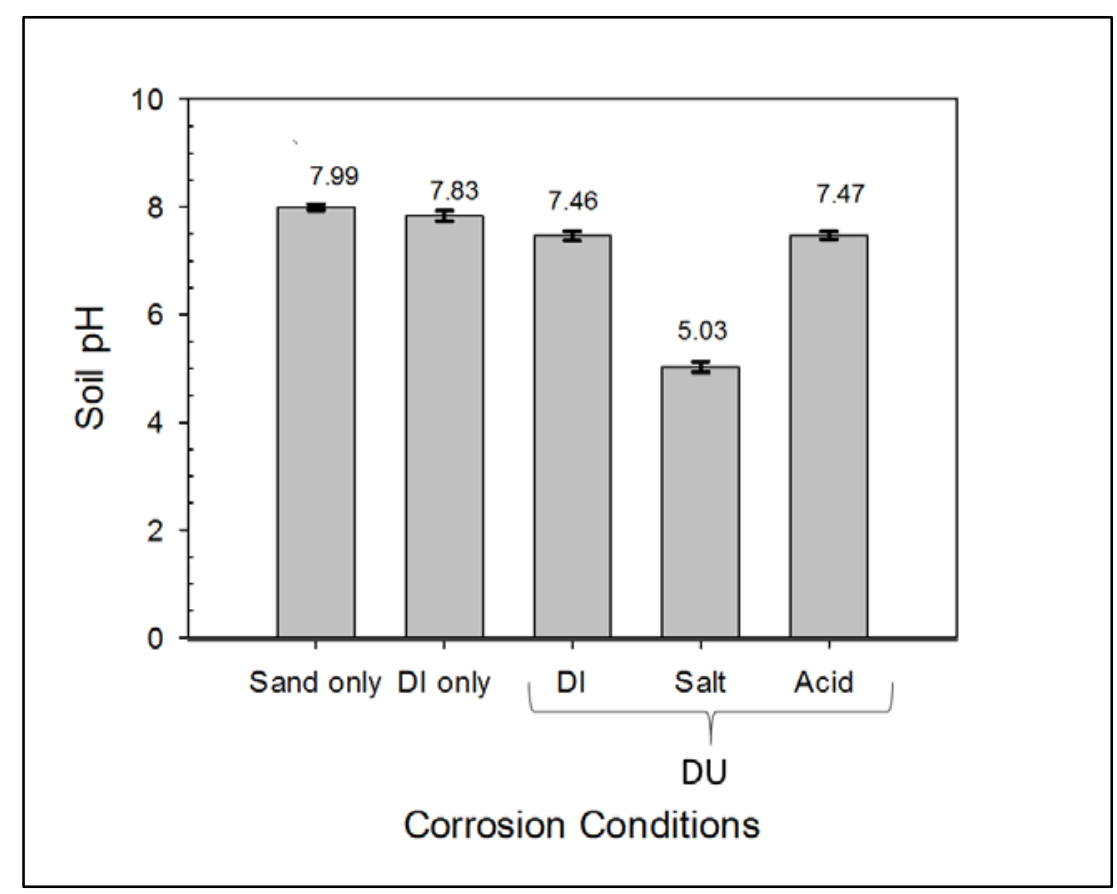

\subsubsection{Corrosion products}

Two types of oxidation products (OP) were removed from the DU fragments. The first was yellow to orange in color and was designated oxidation product 1 (OP1). The second was a black to very dark green material (OP2). Based on descriptions in the literature, it is assumed that OP1 is schoepite and metaschoepite and that $\mathrm{OP} 2$ is uraninite. The first oxidation product was removed from the fragment using a plastic spatula. The second oxidation product was removed using a wire brush.

Figure 6 shows stereomicrographs of the DU fragments after they were cleaned using washing and brushing. Areas where oxidation occurred are visible as yellow and orange coloration. The surface area affected by corrosion is greater on the salt-treated fragment compared to the fragment exposed to DI water. The corrosion product on the water-exposed fragment is mostly yellow; the salt-exposed piece, however, has much more orange 
product. The amount of degradation product on the acid-exposed fragment appears much less than was observed on the water- and salt-exposed penetrator fragments.

Figure 6. Stereomicrograph of cleaned DU solid fragments demonstrating corrosion produced by exposure to $(A)$ distilled water, $(B)$ salt solution, and $(C)$ acid solution.
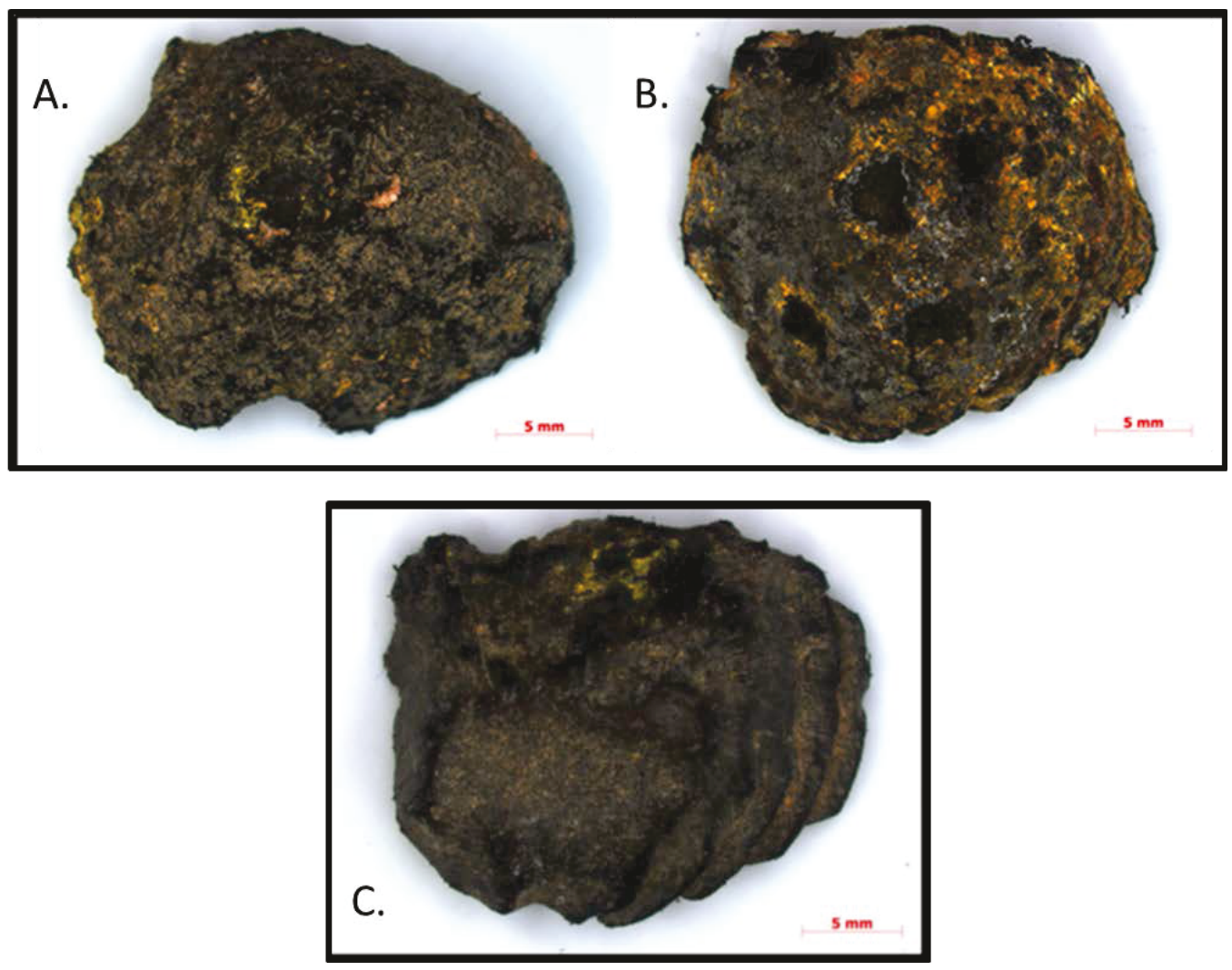

Table 7 documents the mass loss in the DU fragments that were exposed to DI water, salt, and acid solutions. The intermediate weights were obtained without any removal of corrosion product and attached soil material and without any drying of the samples. The final weight included physical removal of the corrosion product and air-drying.

The mass of the DI-treated fragment slightly increased at Day 14 and was about the same as its original mass on Day 28. However, when the corrosion product was removed, its mass decreased about $0.05 \mathrm{~g}$, or about $0.12 \%$ of its original mass. The calculated corrosion rate for the DI-waterexposed fragment was $0.07 \mathrm{~g} \mathrm{~cm}^{2} \mathrm{yr}^{-1}$. 
The coupon exposed to salt solution had steady decreases in its mass throughout the 28 day experiment. When the corrosion product was cleaned, coupon mass had decreased by $1.44 \mathrm{~g}$ (3.63\%), yielding a calculated corrosion rate of $1.96 \mathrm{~g} \mathrm{~cm}^{2} \mathrm{yr}^{-1}$.

The total mass loss from the acid-exposed piece was only $0.01 \mathrm{~g}$ during the 28 -day exposure. This was $0.03 \%$ of its initial mass of $39.5 \mathrm{~g}$. The corrosion rate was calculated to be only $0.01 \mathrm{~g} \mathrm{~cm}^{2} \mathrm{yr}^{-1}$.

Table 7. Mass loss from the DU penetrator rod fragment over time due to corrosion influenced by distilled water or salt solution in the Sand soil type.

\begin{tabular}{|l|c|c|c|}
\hline \multirow{2}{*}{\multicolumn{1}{|c|}{ Time }} & \multicolumn{3}{|c|}{ Sample and weight (g) } \\
\cline { 2 - 4 } & DI + coupon & 3.5\% salt + coupon & SPLP + coupon \\
\hline Day 0 & 40.25 & 39.63 & 39.71 \\
\hline Day 14 & 40.62 & 39.48 & 39.71 \\
\hline Day 28 & 40.52 & 39.14 & 39.74 \\
\hline $\begin{array}{l}\text { Post-removal of } \\
\text { oxidation product }\end{array}$ & 40.47 & 38.91 & 39.70 \\
\hline $\begin{array}{l}\text { Total oxidation } \\
\text { product removed }\end{array}$ & 0.05 & 1.44 & 0.01 \\
\hline
\end{tabular}

Table 8 documents recovered masses of these oxidation products after brushing. For the DI and the salt-solution fragments, the sum of these products does not completely account for the mass lost. Interestingly, the mass recovered for the acid-corroded coupon was greater than that of the total mass loss found by measuring the penetrator rod fragment compared to its initial mass. This could be due to the incorporation of water in the structure of the oxidation product, which is supported in that the final mass (day 28) was somewhat higher for that piece.

Table 8. Masses of oxidation products removed from the corroded DU penetrator rod fragments in the Sand soil type.

\begin{tabular}{|l|c|c|}
\hline \multirow{2}{*}{\multicolumn{1}{|c|}{ Sample }} & \multicolumn{2}{c|}{ Mass $(\mathrm{g})$} \\
\cline { 2 - 3 } & Oxidation Product 1 & Oxidation Product 2 \\
\hline DI + DU coupon & 0.0166 & 0.0151 \\
\hline $3.5 \% \mathrm{NaCl}+\mathrm{DU}$ coupon & 0.7951 & 0.0569 \\
\hline SPLP + DU coupon & 0.0389 & 0.00 \\
\hline
\end{tabular}


Figure 7 shows environmental SEM of DU fragments used in the corrosion experiment. In electron micrographs, light and darkness are relative and are related to density. Lighter areas are from dense materials, and dark areas from less dense materials.

Tables 9 and 10 document electron backscatter analyses at sample points indicated by numbers on the electron micrographs shown in Figure 7 , for DI- and salt-corroded DU penetrator rod pieces, respectively. The first observation is that carbon is found in both samples. As carbon is not part of the formulation of the penetrator rod and the rod was buried in the sand, it was probably deposited as part of the firing process. Electron backscatter on the darkest (least dense) areas indicate that these are about $80 \%$ by mass carbon. The lighter areas appear to be various forms of $\mathrm{U}$ exposed from the general carbon covering.

Figure 7. Scanning electron micrograph (SEM) of coupons that underwent corrosion: $(A)$ DI water and $(B)$ salt solution.
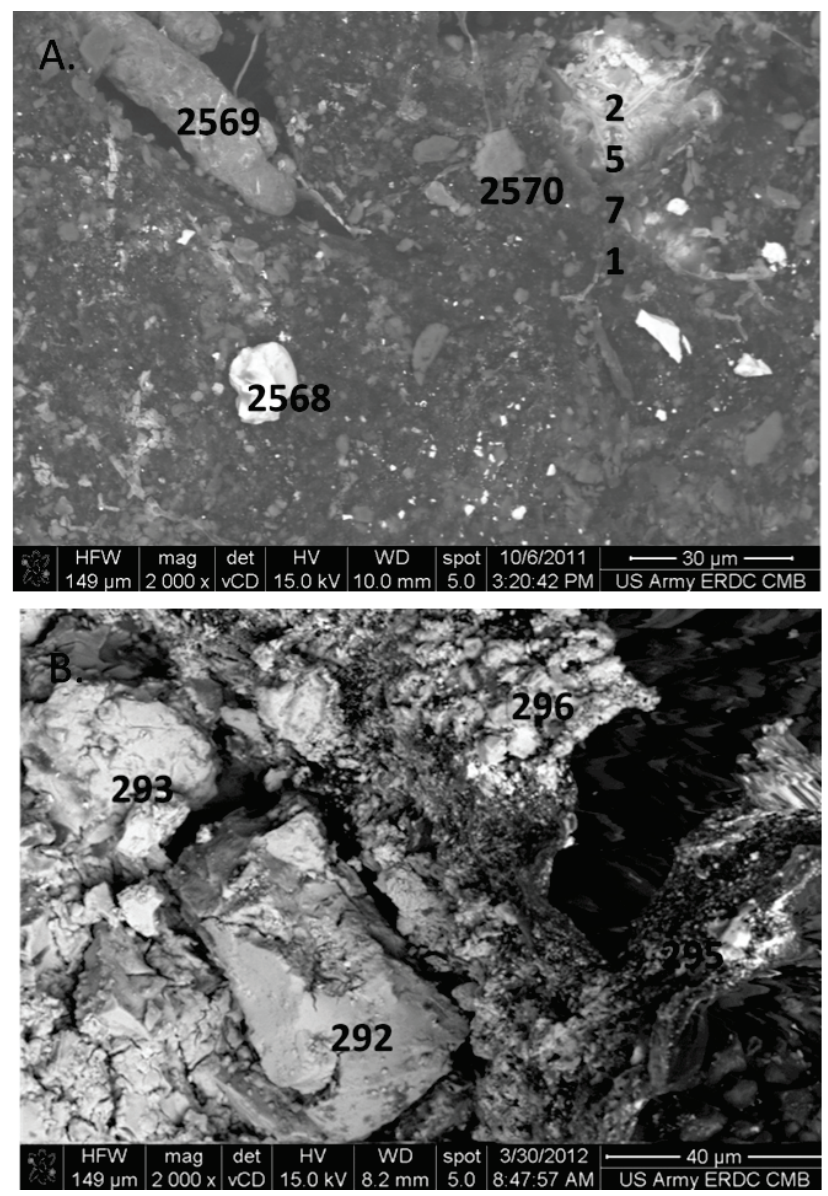
Table 9 documents analysis of the results of the backscatter spectra from the DI-corroded penetrator fragment. Point 2568 is the brightest point on the micrograph, indicating it contains the densest material. This area is, presumably, relatively unaltered DU metal. Its mass percent of $U$ is $45.80 \%$, and oxygen is $21.08 \%$. Point 2570 identifies a portion of the micrograph that is lighter than the background but still dark, indicating that it is more dense than the carbon coating but less dense than other portions. The backscatter profile supports identifying this area as corroded DU. The U mass percent was $8.03 \%$, and oxygen was $43.99 \%$. Point 2569 and Point 2571 are intermediate in brightness between Points 2668 and 2570, and they show weight percent of $U$ and oxygen between these values. Nitrogen was found in only the brightest, and presumably least corroded, portion of the micrograph, Point 2568. Calcium was found in only the most-corroded areas examined (Points 2570 and 2571). The other elements identified by backscatter (e.g., sodium, magnesium, and iron) all showed the same pattern, that is, increasing in percentage mass as the degree of corrosion increased.

Table 9. Mass percent of selected spectra obtained from backscatter analysis of fragments of a DU penetrator rod corroded using DI water.

\begin{tabular}{|l|c|c|c|c|}
\hline \multirow{2}{*}{\multicolumn{1}{|c|}{ Metal }} & \multicolumn{4}{|c|}{ Spectrum point (Figure 7A) } \\
\cline { 2 - 5 } & $\mathbf{2 5 6 8}$ & $\mathbf{2 5 6 9}$ & $\mathbf{2 5 7 0}$ & $\mathbf{2 5 7 1}$ \\
\hline Uranium (U) & 45.80 & 35.92 & 8.03 & 40.24 \\
\hline Aluminum & 0.31 & 0.97 & 7.83 & 1.32 \\
\hline Calcium & ND & ND & 0.86 & 1.76 \\
\hline Carbon & 16.12 & 31.80 & 9.33 & 20.96 \\
\hline Iron & 0.49 & 0.89 & 13.84 & 0.97 \\
\hline Lead & ND & ND & 7.24 & ND \\
\hline Magnesium & 0.02 & 0.34 & 3.40 & 0.22 \\
\hline Nitrogen & 15.01 & ND & ND & ND \\
\hline Oxygen & 21.08 & 27.24 & 43.99 & 31.79 \\
\hline Sodium & 0.001 & 0.20 & 0.48 & 0.25 \\
\hline
\end{tabular}

$\mathrm{ND}=$ nondetect

The DU fragment treated with a salt solution shows a different pattern of corrosion (Table 10). The lower left-hand portion of the micrograph appears to be largely uncorroded zero-valent U. Sample points 292 and 293 
are found in that area; and they are bright, indicating that they are relatively dense. The backscatter spectra from both of these points is high in mass percentage of $U$ ( $91.78 \%$ and $83.05 \%$, respectively) and low in oxygen (0.74\% and $6.54 \%$, respectively). Moving to the upper right hand portion of the micrograph, the micrograph darkens, indicating a change in density. The $\mathrm{U}$ mass percentage decreases (ranging from $61.71 \%$ to $4.02 \%$ ) and the oxygen increases (up to $30.37 \%$ ).

Table 10. Mass percent of selected spectra obtained from backscatter analysis of fragments of a DU penetrator rod corroded using a salt solution.

\begin{tabular}{|l|c|c|c|c|c|}
\hline \multirow{2}{*}{\multicolumn{1}{|c|}{ Metal }} & \multicolumn{5}{c|}{ Spectrum point (Figure 7B) } \\
\cline { 2 - 6 } & $\mathbf{2 9 2}$ & $\mathbf{2 9 3}$ & $\mathbf{2 9 4}$ & $\mathbf{2 9 5}$ & $\mathbf{2 9 6}$ \\
\hline Uranium (U) & 91.78 & 83.05 & 4.02 & 39.09 & 61.71 \\
\hline Aluminum & $\mathrm{ND}$ & $\mathrm{ND}$ & 0.04 & 0.89 & 1.21 \\
\hline Calcium & $\mathrm{ND}$ & $\mathrm{ND}$ & 56.22 & 3.02 & $\mathrm{ND}$ \\
\hline Carbon & 0.82 & 1.62 & 7.54 & 24.92 & 8.00 \\
\hline Chloride & $\mathrm{ND}$ & $\mathrm{ND}$ & $\mathrm{ND}$ & 0.66 & $\mathrm{ND}$ \\
\hline Magnesium & 1.36 & 3.11 & 0.54 & 1.92 & 1.10 \\
\hline Oxygen & 0.74 & 6.54 & 30.37 & 25.35 & 19.67 \\
\hline Silica & $\mathrm{ND}$ & 1.64 & 0.49 & 2.39 & 2.16 \\
\hline Sodium & 5.30 & 5.37 & 0.77 & 3.74 & 6.15 \\
\hline
\end{tabular}

$\mathrm{ND}=$ nondetect

\subsubsection{Effect of soil type}

A second drying-rewetting experiment was initiated to investigate corrosion of DU fragments over time in four soil types plus an uncontaminated Sand control. The physical characteristics of these soils are listed in Tables 2 and 3 of Section 2.1.1. The corrosive agent used was DI water. There were five soil types:

- Clay

- Silty Sand (coarse)

- Sandy Clay

- Silty Sand (fine) 
The purpose of the experiment was to ascertain each soil's corrosion aggressiveness and to establish the contribution of the soil physical and chemical properties to the observed corrosion of the DU fragment. Because soil $\mathrm{pH}$ has an effect on metal corrosion and as corrosion has an effect on soil pH, the $\mathrm{pH}$ was determined both pre- and posttest (Figure 8).

Figure 8. Comparison of change in soil pH before and after depleted uranium corrosion testing in different soil types.

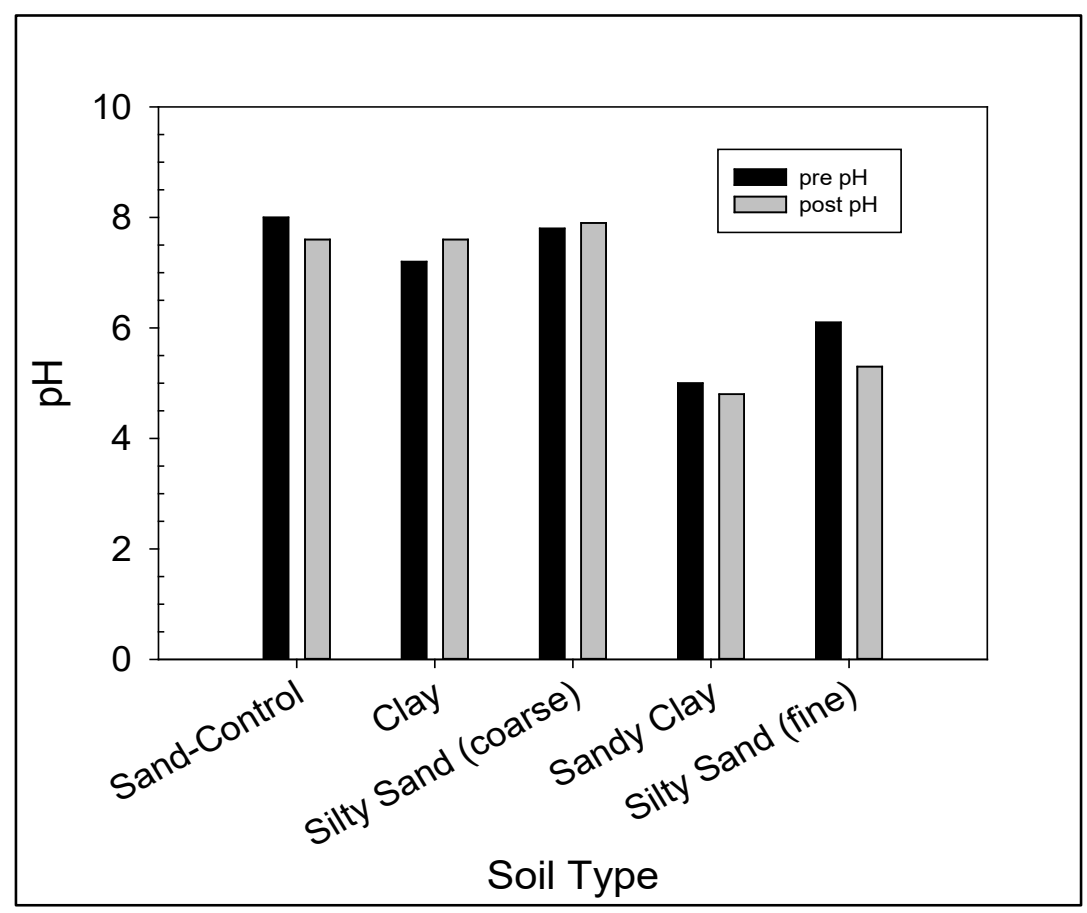

Three of the soil types were observed to drop in $\mathrm{pH}$, and the Clay and coarse Silty Sand demonstrated an increase. The greatest change in $\mathrm{pH}$ from pre- to posttest was observed in the fine Silty Sand soil. Data analysis through a paired t-test reported that the correlation between change in soil $\mathrm{U}$ concentration to soil type $\mathrm{pH}$ was greater than could be expected by chance (two-tailed $\mathrm{P}$-value $=0.032$ at $95 \%$ confidence interval for the difference in means). This confirms the results of Echevarria et al. (2001) and Payne and Harries (2000) who studied $\mathrm{U}\left(\mathrm{UO}_{2}{ }^{2+}\right.$ and $\mathrm{UO}_{2}{ }^{2+}$-carbonate) complexes in arid soils. They concluded that soil $\mathrm{pH}$ far exceeded soil type and organic matter as a controlling factor for U sorption.

In the present study, TOC and soil percent fines were also examined for their effect on the increase in concentration of soil $U$ due to corrosion. A paired t-test found that soil TOC and change in U concentration in these 
five soil types is also significantly correlated (two-tailed P-value $=0.03$ at 95\% confidence interval for difference of means). Similar results were found with soil percent fines (two tailed P-value $=0.032$ ).

Upon completion of the wet-dry study, the corrosion product was removed from the fragments to determine the actual amount of material reacted. As with the different corrosive solutions, two oxidation products were collected from each fragment. The first oxidation product was removed from the fragment using a plastic spatula; the second oxidation product was removed using a wire brush. Oxidation products were also analyzed for total metal concentrations. Table 11 lists the concentrations of post-corrosion metals in the five soils. As with the pretest soils, molybdenum and antimony were not detected in the posttest soils.

Figure 9 shows the increase in concentration of $U$ that occurred in each soil during the 28-day wet-dry cycling. The Clay soil type, which had a slight increase in $\mathrm{pH}$ during the corrosion testing, also had the highest concentration of $\mathrm{U}$ in the soil.

Figure 9. Uranium concentration $\left(\mathrm{mg} \mathrm{kg}^{-1}\right)$ in each soil type at the conclusion of the 28-day wet-dry corrosion test.

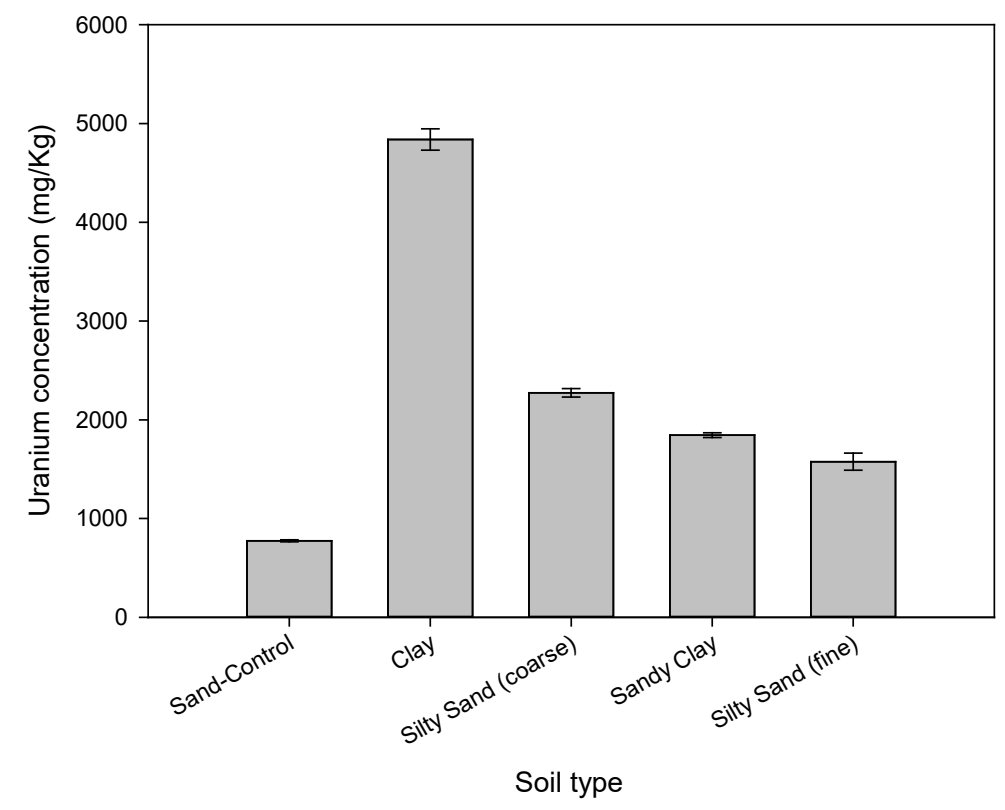


Table 11. Comparison of pre- and post-corrosion metal concentrations for five soil types.

\begin{tabular}{|c|c|c|c|c|c|c|c|c|c|c|}
\hline \multirow[b]{3}{*}{ Metal } & \multicolumn{10}{|c|}{ Soil type } \\
\hline & \multicolumn{2}{|c|}{$\begin{array}{c}\text { Sand } \\
\text { (Control) }\end{array}$} & \multicolumn{2}{|c|}{ Clay } & \multicolumn{2}{|c|}{$\begin{array}{l}\text { Silty Sand } \\
\text { (Coarse) }\end{array}$} & \multicolumn{2}{|c|}{ Sandy Clay } & \multicolumn{2}{|c|}{$\begin{array}{l}\text { Silty Sand } \\
\text { (Fine) }\end{array}$} \\
\hline & Pre- & Post- & Pre- & Post- & Pre- & Post- & Pre- & Post- & Pre- & Post- \\
\hline Uranium (U) & ND & $774 \pm 11$ & $24 \pm 1$ & $4869 \pm 108$ & $13 \pm 1$ & $2274 \pm 43$ & $36 \pm 2$ & $1846 \pm 24$ & $10 \pm 2$ & $1577 \pm 87$ \\
\hline Arsenic & ND & $1 \pm 1$ & ND & $3 \pm 1$ & $6 \pm<1$ & $7 \pm 1$ & ND & ND & ND & $1 \pm 1$ \\
\hline Chromium & ND & $2 \pm<1$ & $20 \pm 1$ & $16 \pm<1$ & $12 \pm 1$ & $10 \pm 1$ & $16 \pm 1$ & $10 \pm<1$ & $8 \pm<1$ & $5 \pm<1$ \\
\hline Iron & $960 \pm 59$ & $596 \pm 70$ & $19,804 \pm 362$ & $13,067 \pm 872$ & $10,806 \pm 23$ & $6867 \pm 563$ & $18,483 \pm 552$ & $12,331 \pm 108$ & $5908 \pm 78$ & $2947 \pm 77$ \\
\hline Lead & ND & $<1 \pm 1$ & $28 \pm 6$ & $12 \pm 2$ & $5 \pm<1$ & $5 \pm 1$ & $9 \pm 1$ & $6 \pm 1$ & $43 \pm 1$ & $33 \pm 1$ \\
\hline Manganese & $14 \pm 2$ & $11 \pm<1$ & $489 \pm 18$ & $407 \pm 8$ & $239 \pm 8$ & $203 \pm 8$ & $203 \pm 8$ & $155 \pm 2$ & $27 \pm 1$ & $18 \pm<1$ \\
\hline Nickel & ND & $<1 \pm 1$ & $18 \pm 1$ & $15 \pm<1$ & $13 \pm 1$ & $11 \pm 1$ & $17 \pm 1$ & $12 \pm<1$ & ND & $2 \pm<1$ \\
\hline Zinc & ND & $2 \pm 1$ & $45 \pm 1$ & $33 \pm 3$ & $32 \pm 2$ & $24 \pm 1$ & $65 \pm 1$ & $38 \pm 1$ & $9 \pm 2$ & $4 \pm<1$ \\
\hline
\end{tabular}


To examine the significance of $\mathrm{pH}$ and the other soil type characteristics, a paired t-test was performed on the independent variables against change in $\mathrm{U}$ soil concentration. The variables examined were percent fines, soil $\mathrm{pH}$, percent TOC, and CEC. However, each variable was determined to be significant (Table 12).

Table 12. Relationship between independent variables of soil type and increase in uranium concentration during corrosion studies.

\begin{tabular}{|c|c|c|c|}
\hline $\begin{array}{c}\text { Independent } \\
\text { variable }\end{array}$ & $\mathbf{t}$ & $\mathbf{P}$ & Significant \\
\hline $\mathrm{pH}$ & 3.245 & 0.0315 & Yes \\
\hline$\%$ fines & 3.236 & 0.0318 & Yes \\
\hline CEC & 3.254 & 0.0313 & Yes \\
\hline TOC & 3.297 & 0.0300 & Yes \\
\hline
\end{tabular}

Multiple linear regression analyses were then used to compare the effect of combinations of the independent variables on the change in the soil concentration of $\mathrm{U}$ before and after corrosion testing (Table 13). When $\mathrm{pH}$, CEC, and TOC were considered together, the $R^{2}$ was 0.892 . However, the variance inflation factor (VIF) for each variable was greater than 5 ; and in the case of $\mathrm{pH}$ and CEC, the VIF was 24.89 and 17.67, respectively, indicating a high degree of multicollinearity between the variables. When the variables were percent fines, CEC, and TOC, the $R^{2}$ was 0.804 ; but the VIF for each variable dropped to $1.996,3.890$, and 5.432, respectively. In each analysis, TOC was reported as the variable with the highest degree of multicollinearity. When percent fines and $\mathrm{pH}$ were considered together, the VIF dropped to 2.027 for both. When percent fines was considered along with CEC, the VIF dropped to 1.379 , an acceptable level of interaction between variables.

Taking these calculations back to soil type, the greatest increase in U concentration was found in the Clay soil type. This soil had the lowest TOC and CEC of the five soil types and a medium range of $\mathrm{pH}$ and percent fines. Principal component analysis will be required to elucidate the rankings of these soil characteristics for their effect on the increase of soil $U$ due to corrosion. 
Table 13. Results of multiple linear regression analysis of independent soil variables on soil.

\begin{tabular}{|c|c|c|c|c|c|}
\hline Analysis & Coefficient & Std. error & $\mathrm{t}$ & $P$ & VIF \\
\hline Analysis 1 & \multicolumn{5}{|c|}{$R^{2}=0.892$} \\
\hline Constant & 32978.631 & 16563.296 & 1.991 & 0.296 & \\
\hline $\mathrm{pH}$ & -4014.620 & 2030.687 & -1.977 & 0.298 & 24.894 \\
\hline CEC & -1105.658 & 407.714 & -2.712 & 0.225 & 17.674 \\
\hline TOC & 0.0857 & 0.191 & 0.449 & 0.731 & 5.436 \\
\hline Analysis 2 & \multicolumn{5}{|c|}{$R^{2}=0.804$} \\
\hline Constant & 845.088 & 1855.061 & 0.456 & 0.728 & \\
\hline$\%$ fines & 34.147 & 26.132 & 1.307 & 0.416 & 1.996 \\
\hline CEC & -327.373 & 257.531 & -1.271 & 0.424 & 3.890 \\
\hline TOC & 0.109 & 0.257 & 0.425 & 0.744 & 5.432 \\
\hline Analysis 3 & \multicolumn{5}{|c|}{$R^{2}=0.769$} \\
\hline Constant & 1511.894 & 758.779 & 1.993 & 0.185 & \\
\hline$\%$ fines & 40.315 & 16.687 & 2.416 & 0.137 & 1.379 \\
\hline CEC & -239.516 & 117.810 & -2.033 & 0.179 & 1.379 \\
\hline Analysis 4 & \multicolumn{5}{|c|}{$R^{2}=0.735$} \\
\hline Constant & -7878.273 & 5085.346 & -1.549 & 0.261 & \\
\hline$\%$ fines & 50.758 & 21.650 & 2.344 & 0.144 & 2.027 \\
\hline $\mathrm{pH}$ & 1175.056 & 641.453 & 1.832 & 0.208 & 2.027 \\
\hline
\end{tabular}

\subsubsection{Leaching of DU and other metals}

Table 14 shows the results of the DDI S\&S water leach procedure performed on the test soils prior to DU corrosion testing. In the pretest soil, iron and manganese were present in most soils with the exception of the two grades of Silty Sand, coarse and fine. Uranium was not detected in any of the pretest soils.

Table 14 also shows the results of the DDI S\&S leach procedure performed on the test soils after the DU corrosion testing. Uranium was present in the leachate of each soil type. Greatest $U$ leaching was seen in the Clay soil (13 $\mathrm{mg} \mathrm{L}^{-1}$ ) followed by the Sandy Clay and the Sand with 7 and $6 \mathrm{mg} \mathrm{L}^{-1}$, respectively. Iron leaching increased in the Sand (Control) and the Clay soil types. Manganese leaching decreased in the Sand, Clay, Sandy Clay and fine Silty Sand soils. 
Table 14. Metal concentrations ( $\left.\mathrm{mg} \mathrm{L}^{-1}\right)$ in leachate produced by the DDI S\&S leach test performed on pre-and post-corrosion testing soils.

\begin{tabular}{|l|c|c|c|c|c|c|c|c|c|c|}
\hline \multirow{3}{*}{\multicolumn{1}{c|}{ Metal }} & \multicolumn{9}{|c|}{ Soil type } \\
\cline { 2 - 13 } & \multicolumn{2}{|c|}{ Sand (Control) } & \multicolumn{2}{|c|}{ Clay } & \multicolumn{1}{c|}{ Silty Sand (Coarse) } & \multicolumn{2}{c|}{ Sandy Clay } & \multicolumn{2}{c|}{ Silty Sand (Fine) } \\
\cline { 2 - 13 }$y$ & Pre- & Post- & Pre- & Post- & Pre- & Post- & Pre- & Post- & Pre- & Post- \\
\hline Uranium (U) & ND & $5.82 \pm 0.43$ & ND & $13.11 \pm 2.46$ & ND & $0.23 \pm 0.15$ & ND & $6.66 \pm 3.68$ & ND & $3.23 \pm 0.34$ \\
\hline Arsenic & ND & ND & ND & ND & ND & ND & ND & ND & ND & ND \\
\hline Chromium & ND & ND & ND & ND & ND & ND & ND & ND & ND & ND \\
\hline Copper & ND & ND & ND & ND & ND & ND & ND & ND & ND & ND \\
\hline Iron & $0.74 \pm 0.02$ & $1.03 \pm 0.01$ & $0.16 \pm 0.01$ & $0.26 \pm 0.08$ & ND & ND & $0.17 \pm 0.03$ & $0.08 \pm 0.03$ & ND & ND \\
\hline Lead & ND & ND & ND & ND & ND & ND & ND & ND & ND & ND \\
\hline Manganese & $0.74 \pm 0.01$ & $0.03 \pm 0.00$ & $0.04 \pm 0.01$ & ND & ND & ND & $0.24 \pm 0.02$ & $0.1 \pm 0.00$ & $0.05 \pm 0.00$ & $0.04 \pm 0.01$ \\
\hline Nickel & ND & ND & ND & ND & ND & ND & ND & ND & ND & ND \\
\hline Zinc & ND & ND & ND & ND & ND & ND & ND & ND & ND & ND \\
\hline
\end{tabular}

$\mathrm{ND}=$ nondetect 
For comparison, Table 15 shows the results of the TCLP test on post-corrosion soils. TCLP is a much more aggressive leaching procedure. The TCLP leached the highest concentrations of $U$ from the test soils; and of those, the highest $\mathrm{U}$ concentrations were observed in leachates from the Clay soil type. Higher concentrations of most metals were seen in all experimental soil types compared to the DDI S\&S leach results.

Table 15. Metal concentrations in leachate produced by the TCLP leach test performed on post-corrosion testing soils.

\begin{tabular}{|l|c|c|c|c|c|}
\hline \multirow{2}{*}{ Metal } & \multicolumn{5}{|c|}{ Soil } \\
\cline { 2 - 6 } & $\begin{array}{c}\text { Sand } \\
\text { (Control) }\end{array}$ & Clay & $\begin{array}{c}\text { Silty Sand } \\
\text { (coarse) }\end{array}$ & Sandy clay & $\begin{array}{c}\text { Silty Sand } \\
\text { (fine) }\end{array}$ \\
\hline Uranium (U) & $0.06 \pm 0.02$ & $232.70 \pm 51.53$ & $62.01 \pm 5.18$ & $80.35 \pm 31.45$ & $65.03 \pm 20.56$ \\
\hline Arsenic & $\mathrm{ND}$ & $\mathrm{ND}$ & $\mathrm{ND}$ & $\mathrm{ND}$ & $\mathrm{ND}$ \\
\hline Chromium & $\mathrm{ND}$ & $0.16 \pm 0.04$ & $0.04 \pm 0.00$ & $0.06 \pm 0.02$ & $0.04 \pm 0.01$ \\
\hline Copper & $\mathrm{ND}$ & $0.54 \pm 0.12$ & $0.17 \pm 0.01$ & $0.19 \pm 0.00$ & $0.14 \pm 0.05$ \\
\hline Iron & $\mathrm{ND}$ & $\mathrm{ND}$ & $\mathrm{ND}$ & $0.08 \pm 0.03$ & $\mathrm{ND}$ \\
\hline Lead & $\mathrm{ND}$ & $0.04 \pm 0.01$ & $0.88 \pm 0.09$ & $\mathrm{ND}$ & $\mathrm{ND}$ \\
\hline Manganese & $0.10 \pm 0.00$ & $4.03 \pm 0.05$ & $0.51 \pm 0.03$ & $1.24 \pm 0.07$ & $0.21 \pm 0.01$ \\
\hline Nickel & $\mathrm{ND}$ & $0.09 \pm 0.01$ & $0.03 \pm 0.00$ & $0.05 \pm 0.01$ & $0.03 \pm 0.01$ \\
\hline Zinc & $\mathrm{ND}$ & $\mathrm{ND}$ & $\mathrm{ND}$ & $0.05 \pm 0.02$ & $\mathrm{ND}$ \\
\hline
\end{tabular}

$\mathrm{ND}=$ nondetect

Table 16 shows the results of the SPLP leach procedure performed on the test soils after the DU corrosion testing. The SPLP differs from the TCLP in the use of less-aggressive extraction fluids. This test is designed to simulate the leaching effects from material sitting on the surface of the ground and exposed to weathering, with the assumption that the precipitation is only slightly acidic. Uranium concentrations were higher than found in DDI S\&S leaching but lower than the TCLP leachates. Fewer metals were detected in the SPLP leachates in fewer soil types and at lower concentrations than with the TCLP leachates. 
Table 16. Metal concentrations in leachate produced by the SPLP leach test performed on post-corrosion testing soils.

\begin{tabular}{|l|c|c|c|c|c|}
\hline \multirow{2}{*}{ Metal } & \multicolumn{5}{|c|}{ Soil } \\
\cline { 2 - 6 } & $\begin{array}{c}\text { Sand } \\
\text { (Control) }\end{array}$ & Clay & $\begin{array}{c}\text { Silty Sand } \\
\text { (coarse) }\end{array}$ & Sandy Clay & $\begin{array}{c}\text { Silty Sand } \\
\text { (fine) }\end{array}$ \\
\cline { 2 - 7 } Uranium (U) & ND & $9.42 \pm 0.67$ & $6.20 \pm 0.40$ & $5.85 \pm 0.29$ & $13.38 \pm 1.08$ \\
\hline Arsenic & ND & ND & ND & ND & ND \\
\hline Chromium & ND & ND & ND & ND & ND \\
\hline Copper & ND & $24.88 \pm 2.26$ & ND & ND & $0.03 \pm 0.00$ \\
\hline Iron & $0.20 \pm 0.08$ & $0.59 \pm 0.27$ & ND & ND & ND \\
\hline Lead & ND & ND & ND & ND & ND \\
\hline Manganese & $0.03 \pm 0.00$ & ND & $0.11 \pm 0.01$ & $0.24 \pm 0.00$ & ND \\
\hline Nickel & ND & ND & ND & ND & ND \\
\hline Zinc & ND & ND & ND & ND & ND \\
\hline
\end{tabular}

$\mathrm{ND}=$ nondetect

\subsection{Migration of corrosion products}

All migration studies were conducted in columns filled with uncontaminated sand. At the conclusion of the DU migration study, the columns were disassembled, and sand samples were collected at $2.54 \mathrm{~cm}$ (1 in.) intervals. Each depth sample was analyzed for $\mathrm{pH}$ (Figure 10) and concentration of total metals (Table 17). In addition, each depth sample was tested using the leach tests to observe the retention capability of the U species on the sand (Figure 10).

Figure 10. Soil pH by depth in column study of DU migration.

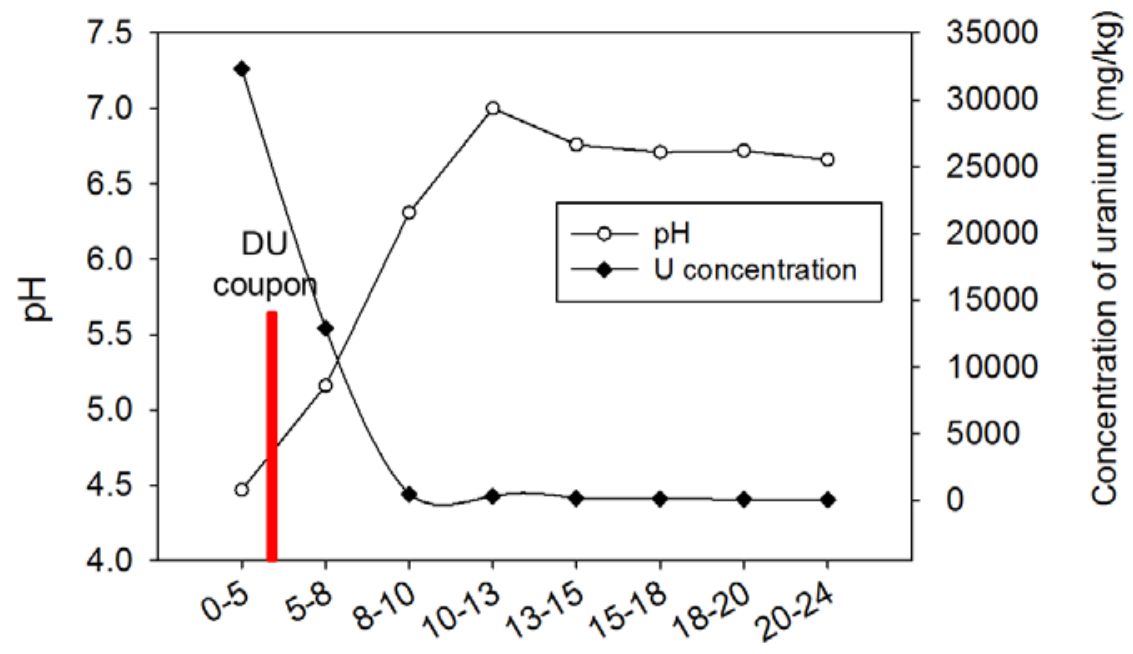

Depth (cm) 
Table 17. Metal concentration ( $\mathrm{mg} \mathrm{kg}^{-1}$ ) by depth of post-leaching column sand.

\begin{tabular}{|c|c|c|c|c|c|c|c|c|c|c|c|c|c|c|}
\hline \multirow[b]{3}{*}{ Depth (cm) } & \multicolumn{14}{|c|}{ Metal concentration (mg kg-1) } \\
\hline & \multicolumn{2}{|c|}{ Uranium } & \multicolumn{2}{|c|}{ Lead } & \multicolumn{2}{|c|}{ Copper } & \multicolumn{2}{|c|}{ Iron } & \multicolumn{2}{|c|}{ Manganese } & \multicolumn{2}{|c|}{ Magnesium } & \multicolumn{2}{|c|}{ Calcium } \\
\hline & avg & stdev & avg & stdev & avg & stdev & avg & stdev & avg & stdev & avg & stdev & avg & stdev \\
\hline $0-5.08$ & $32,333.33$ & 41.63 & 9.94 & 2.48 & 75.37 & 0.38 & 835.33 & 33.58 & 18.38 & 0.39 & 111.23 & 11.51 & 64.81 & 14.18 \\
\hline $5.08-7.62$ & $12,926.00$ & 842.30 & 6.33 & 1.00 & 30.25 & 1.43 & $1,090.13$ & 176.34 & 19.35 & 0.89 & 68.39 & 4.96 & 63.36 & 11.56 \\
\hline $7.62-10.16$ & 478.60 & 19.79 & 5.73 & 0.87 & ND & ND & 973.33 & 63.30 & 14.53 & 0.58 & 65.11 & 4.34 & 96.92 & 1.91 \\
\hline $10.16-12.7$ & 312.53 & 2.48 & 5.34 & 0.14 & ND & ND & $1,072.13$ & 47.98 & 19.09 & 0.22 & 67.49 & 8.54 & 83.95 & 7.67 \\
\hline $12.7-15.24$ & 169.53 & 14.20 & ND & ND & ND & ND & $1,003.93$ & 86.21 & 16.30 & 1.56 & 60.15 & 7.18 & 80.97 & 12.58 \\
\hline $15.24-17.78$ & 118.61 & 6.77 & ND & ND & ND & ND & 813.07 & 76.43 & 16.67 & 1.55 & 54.47 & 4.09 & 74.60 & 4.39 \\
\hline $17.78-20.32$ & 78.45 & 1.80 & ND & ND & ND & ND & 870.13 & 42.79 & 15.15 & 0.42 & 54.53 & 3.33 & 75.15 & 12.83 \\
\hline $20.32-24.13$ & 50.93 & 1.57 & ND & ND & ND & ND & 774.40 & 49.63 & 14.56 & 0.41 & 54.81 & 1.51 & 76.40 & 4.88 \\
\hline
\end{tabular}

$\mathrm{ND}=$ nondetect

stdev $=$ standard deviation 
Uranium concentration was greatest immediately above the coupon $\left(32,000 \mathrm{mg} \mathrm{Kg}^{-1}\right)$, indicating that $\mathrm{U}$ first migrated upward from the coupon. Concentration then decreased steadily with depth $\left(51 \mathrm{mg} \mathrm{Kg}^{-1}\right)$.

DDI S\&S leach tests indicated that U leachability was greater in the upper $5 \mathrm{~cm}$ of soil than at any other depth (Table 18). The U concentration ranged from $170.17 \mathrm{mg} \mathrm{L}^{-1}$ at $0-5 \mathrm{~cm}$ to $0.07 \mathrm{mg} \mathrm{L}^{-1}$ at $20-24 \mathrm{~cm}$.

Table 18. Post-migration uranium concentrations by depth in leachate using the DDI S\&S leaching test.

\begin{tabular}{|l|c|c|}
\hline $\begin{array}{c}\text { Depth } \\
(\mathrm{cm})\end{array}$ & $\begin{array}{c}\text { Uranium concentration } \\
\left(\mathrm{mg} \mathrm{L}^{-1}\right)\end{array}$ & stdev \\
\hline $0-5.08$ & 170.17 & 6.63 \\
\hline $5.08-7.62$ & 0.73 & 0.26 \\
\hline $7.62-10.16$ & 2.28 & 0.34 \\
\hline $10.16-12.7$ & 1.89 & 0.15 \\
\hline $12.7-15.24$ & 0.73 & 0.19 \\
\hline $15.24-17.78$ & 0.31 & 0.08 \\
\hline $17.78-20.32$ & 0.37 & 0.04 \\
\hline $20.32-24.13$ & 0.07 & 0.04 \\
\hline
\end{tabular}

TCLP was the most aggressive of the leaching tests used in this study. Table 19 reports the results of the TCLP leaching of $U$ from the post-corrosion soil samples by depth. As with the SPLP, the TCLP extracted the greatest amount of $U$ in the upper $5 \mathrm{~cm}$ of soil. Decreasing concentrations of $U$ were extracted with depth in the column (i.e., distance from the coupon). Much higher concentrations of TCLP-extractable U were found close to the coupon than with the SPLP.

Table 19. Post-migration uranium concentrations by depth in leachate using the TCLP.

\begin{tabular}{|l|c|c|}
\hline $\begin{array}{c}\text { Depth } \\
(\mathrm{cm})\end{array}$ & $\begin{array}{c}\text { TCLP Uranium Concentration } \\
\left(\mathrm{mg} \mathrm{L}^{-1}\right)\end{array}$ & stdev \\
\hline $0-5.08$ & 613.0 & 44.40 \\
\hline $5.08-7.62$ & 187.0 & 31.44 \\
\hline $7.62-10.16$ & 17.97 & 1.37 \\
\hline $10.16-12.7$ & 11.05 & 0.13 \\
\hline $12.7-15.24$ & 6.25 & 0.20 \\
\hline $15.24-17.78$ & 3.91 & 0.23 \\
\hline $17.78-20.32$ & 3.41 & 1.04 \\
\hline $20.32-24.13$ & 2.00 & 0.05 \\
\hline
\end{tabular}




\section{Discussion}

\subsection{Corrosion rates}

This corrosion study was of relatively short duration (28 days) compared to others presented in the literature. For example, the Handley-Sidhu et al. (2009b, 2009c) studies lasted 510 days; and the study conducted by Schimmack et al. (2007) ran for 3 years. Chen and Yiacoumi (2002) suggested that overall transport of DU is slow due to the relatively slow oxidation of DU from the penetrator rod. However, the corrosion rates found in this study were comparable to rates found in these other studies. The highest corrosion rate $\left(1.96 \mathrm{~g} \mathrm{~cm}^{-2} \mathrm{y}^{-1}\right)$ was found for the $3.5 \mathrm{NaCl}$ solution. However the lowest corrosion rate was found for the acidic solution ( $0.01 \mathrm{~g}$ $\mathrm{cm}^{-2} \mathrm{y}^{-1}$ ), which had a rate seven times lower than the DI solution. Uranium tends to be less mobile in lower $\mathrm{pH}$ environments (Echevarria et al. 2001; Payne and Harries 2000), which may explain the lower corrosion rates obtained with the acidic solution.

Further, using wet-dry cycles in this study is a more aggressive approach than found in other laboratory studies, which have focused on maintaining field moist or saturated conditions (Handley-Sidhu et al. 2009b, 2009c; Schimmack et al. 2007). Consequently, we found significant corrosion in 28 days, with corrosive products clearly visible at the surface of the soil column treated with salt solution after just 14 days. This study represents a more aggressive weathering approach than found over a long period of time for most environments. In fact, one field study did not find any significant corrosion in 250 days of exposure in a desert environment (Baltz 2000). However, in short periods, the weathering conditions could roughly mimic our wet-dry cycle approach. This suggests that DU corrosion maybe tied to periods when weathering is most aggressive as opposed to total exposure time.

\subsection{Interactions with corrosion products}

There appear to be interactions between the penetrator rod, corrosion products, and sand media that occur rather rapidly and affect the mobility of the oxidized $U$. When the most-corroded fragments of the penetrator rod were removed from the sand matrix, we observed that sand was stuck to the pieces (Figure 4) and could be removed only by brushing. SEM with EDS analysis indicated that more-corroded DU portions have higher levels 
of iron, aluminum, and silica than the less corroded portions (Tables 9 and 10). Although some of these elements were detected at relatively low levels, which may be within the variability of the EDS technique, the pattern is persuasive. These elements were found in the sand matrix. It appears that there is interplay with the corroded portions on the penetrator rod with elements in the sand.

\subsection{Migration of uranium}

The interaction between the penetrator rod, corrosion products, and sand media also appears to play a role in the migration of the oxidation products to the sand media. The salt-treated penetrator rod fragment had the greatest mass loss due to corrosion, but a lower percentage of this mass migrated to the sand matrix (40\%). This piece also had the greatest amount of soil attached to it when removed. Conversely, the acid-treated piece had the lowest amount of actual corrosion, the least amount of sand attached to it, and the highest percentage of DU migration into the sand. However, because the amount of DU corrosion product for the salt solution was two orders of magnitude higher than that for the acid, the overall $\mathrm{U}$ in the sand was highest for the salt treatment.

In a similar manner, oxidation products that have migrated into the sand matrix appear to have interacted with the sand material (Figures 4 and 6). Oliver et al. (2008a) found that DU was associated and migrated with organic colloids in the soil pore water. Crancon et al. (2010), studying transport of surficially deposited $U$ in soils, found migration from the source appeared to be controlled by humic and clayey soil deposits. While movement of dissolved $U$ was slow, transport was greatly increased if $U$ was complexed with humic colloids. In our study, it was found that the DDI S\&S leach test could only extract $1.97 \%$ of the corrosion products that have migrated in the sand. SEM micrographs showed that small (on the order of 10 to $15 \mu \mathrm{m}$ ) pieces of $U$ were intermingled with the sand matrix, possibly incorporated into the silica (Figure 7). These pieces would, presumably, be mobile in flowing water. Further, small particles this size could be very susceptible to dissolution. So, the formation of these small particles could result in increased DU mobility. This is consistent with findings of Török et al. (2004) using DU from soils collected from Kosovo that had been exposed to penetrator rods. They found that the soil particles contained ultrafine $\mathrm{U}$ derived from the rods. In that study, the soils had been exposed to the penetrators for several years. Our effect appears 
to have occurred within days. Consequently, these results indicate that interactions between the penetrator rod, the oxidation products, and the sand greatly affect the movement of the oxidation product and that these interactions can occur relatively rapidly. These interactions with the sand media may account for the low U recovery achieved by the DDI S\&S extraction. This suggests that this reaction could immobilize corroded DU from leaching. However, the sand grains themselves could be suspended and mobilized by flowing water.

\subsection{Upward migration of uranium}

One of our first observations was that DU corrosion products have the tendency to migrate upwards, as seen in Table 17. This may be a factor of expansion of the corrosion products and a wicking-like effect that draws the corrosion product away from the source. If corrosion can draw oxidized $\mathrm{U}$ to the surface, then it could allow for migration via surface-water runoff. Such migration could spread contamination over a much wider surface area than could migrate in the subsurface.

\subsection{Oxidation products}

Oxidation products were comparable to those found in other studies although it appears that the majority of products found in this study were intermediate oxidized forms (such as U dioxide and uraninite). Metaschoepite has been the primary form of oxidation product found in the field (Salbu et al. 2005; Lind et al. 2009).

\subsection{Soil type}

Soil type had an interesting effect on DU corrosion. This study reports that soils with fine material had substantially greater DU corrosion release under comparable conditions than those of just sand only. The highest amount of corroded DU was found in the Clay soil type. It appears that the fine material allows more effective chemical reactions at the DU metallic surface. Perhaps the fine material also helped hold more water near the penetrator rod metal compared to sand, which would drain better. This supports the use of sand in catch boxes as opposed to soil. 


\section{Conclusions}

The most uncertain aspect of uranium in the environment is the transport resulting from the corrosive release of oxidation products. This study focused on short-term (time frame of weeks) corrosion of DU under differing environmental conditions to characterize rates and $U$ species formed. This study lead to the following conclusions:

- DU corrosion ranged from 0.01 to $1.96 \mathrm{~g} \mathrm{~cm}^{-2} \mathrm{y}^{-1}$. The highest rate was obtained for the salt treatment, the lowest for acid. The rapid corrosion of the DU used in the salt test suggests the potential for rapid dissolution and migration of DU species in marine and estuarine environments.

- Two oxidation products were identified: black and yellow. The majority of products found in this study were intermediate oxidized forms (such as $\mathrm{U}$ dioxide and uraninite).

- Approximately $40 \%$ to $80 \%$ of the corroded DU migrated into the sand. The greater the overall corrosion, the lower the percentage of migration.

- Of the material that migrated into the sand, less than $2 \%$ washed off into deionized water when using the DDI S\&S test. The remaining material appeared to be strongly bound to the sand matrix. These tests should be repeated with marine and estuarine sediment.

- SEM investigation with EDS analysis indicate that the fired DU pieces had been coated with carbon. Relatively uncorroded DU was nearly 90 mass percent $\mathrm{U}$. Corroded DU decreased in mass percent of $\mathrm{U}$ and increased in oxygen content. Other elements increased in mass percentage as corrosion increased, possibly as incorporation from the sand media or from simple mass-balance relationships as the $\mathrm{U}$ decreased.

- Very small (10 to $15 \mu \mathrm{m}$ diameter) particles of $U$ were found in the sand matrix. These particles could be mobile in the presence of moving water and possibly susceptible to dissolution.

- Interactions with the penetrator rod, oxidation products, and the sand matrix appear to affect the dissolution of the corroded DU; and these interactions appear to occur rather rapidly. The sand grains themselves, however, could be transported by moving water, removing the DU from the penetrator rod.

- Soils with fine material resulted in higher levels of DU corrosion. Again, this suggests the potential for greater rates of corrosion and DU product transport in marine and estuarine environments. 
Multiple soil physical and chemical characteristics appear to contribute to differences in the rates of corrosion among soil types, including soil $\mathrm{pH}$, percentage of soil fines, and total organic carbon content. These studies suggest that limiting moisture and salt exposure could reduce corrosion of exposed DU and subsequent migration. In the short term, actions to limit DU corrosion might include removing soil from catch box areas and replacing it with sand. 


\section{References}

Abdelouas, A., Y. Lu, W. Lutze, and H. E. Nuttall. 1998. Uranium Contamination in the Subsurface: Characterization and Remediation. In Uraniun: Mineralogy, Geochemistry, and the Environment, ed. P. C. Burns, and R. Finch, 433-473. Washington, DC: Mineralogical Society of America.

ASTM (American Society of Testing and Materials International). 2011. Standard Practice for Classification of Soils for Engineering Purposes (United Soil Classification System). ASTM D2487. West Conshohocken, PA: ASTM International.

- 2013. Standard Test Method for pH in Soils. ASTM D4972. West Conshohocken, PA: ASTM International.

Baltz, J. 200o. The Corrosion and Chemical Speciation of Depleted Uranium (DU) Munitions at the US Army Yuma Proving Grounds. MS thesis, University of New Mexico, Albuquerque.

Barnett, M. O., P. M. Jardine, S. C. Brooks, and H. M. Selim. 200o. Adsorption and Transport of Uranium (VI) in Subsurface Media. Soil Science Society of America Journal 64:908-917.

Bednar, A., V. F. Medina, D. Ulmer-Scholle, B. Frey, W. Brostoff, B. L. Johnson, and S. L. Larson. 2007. Effects of Organic Matter on the Speciation of Uranium in Soil and Plant Matrices. Chemosphere 70:237-247. doi: 10.1016/j.chemosphere.2007. 06.032.

Bernhard, G., G. Geipel, V. Brendler, and H. Nitsche. 1998. Uranium Speciation in Waters of Different Uranium Mining Areas. Journal of Alloys and Compounds 271273:201-205.

Betti, M. 2003. Civil Use of Depleted Uranium. Journal of Environmental Radioactivity 64:113-119.

Bhainsa, K. C., and S. F. D’Souza. 2001. Uranium(VI) Biosorption by Dried Roots and Eichhornia Crassipes (Water Hyacinth). Journal of Environmental Science and Health, Part A 36 (9): 1621-1631.

Bradbury, M. H., and B. Baeyens. 2005. Modelling the Sorption of Mn(II), Co(II), Ni(II), Zn(II), Cd(II), Eu(III), Am(III), Sn(IV), Th(IV), Np(V), and U(VI) on Montmorillonite: Linear Free Energy Relationships and Estimates of Surface Binding Constants for Some Selected Heavy Metals and Actinides. Geochimica et Cosmochimica Acta. 69:875-892.

Buck, B. J., A. L. Brock, W. H. Johnson, and A. L. Ulery. 2004. Corrosion of Depleted Uranium in an Arid Environment: Soil-Geomorphology, SEM/EDS, XRD, and Electron Microprobe Analyses. Soil and Sediment Contamination 13 (6): 545561. doi: 10.1080/10588330490519437. 
Burns, S. F., R. H. Thompson, J. N. Beck, and J. R. Meriwether. 1991. Thorium, Uranium, and Cesium-137 in Louisiana Soils: Migration Trends in a Soil Catena near Dubach, Louisiana, USA. Radiochimica Acta 52-53 (1): 241-247.

Butler, A. D., M. Wynter, V. F. Medina, and A. J. Bednar. 2016. Depleted Uranium Toxicity, Accumulation, and Uptake in Cynodon dactylon (Bermuda) and Aristida purpurea (Purple Threeawn). Bulletin of Environmental Contamination and Toxicology 96 (6): 714-719. doi: 10.1007/s00128-016-1784-9.

Chen, J. P., and S. Yiacoumi. 2002. Modeling of DU Transport in Subsurface Systems. Water, Air \& Soil Pollution 140:173-201.

Christ, C. L., and J. R. Clark. 1960. Crystal Chemical Studies on Some Uranyl Oxide Hydrates. The American Mineralogist 45:1026-1051.

Conca, J., E. Strietelmeier, N. Lu, S. D. Ware, T. P. Taylor, J. Kaszuba, and J. Wright. 2002. Treatability Study of Reactive Materials to Remediate Groundwater Contaminated with Radionuclides, Metals, and Nitrates in a Four-Component Permeable Reactive Barrier. In Handbook of Groundwater Remediation Using Permeable Reactive Barriers: Applications to Radionuclides, Trace Metals, and Nutrients, ed. D. L. Naftz, S. J. Morrison, C. C. Fuller, and J. A. Davis, 221-252. Elsevier Science.

Craft, E. S., A. W. Abu-Qare, M. M. Flaherty, M. C. Garofolo, H. L. Rincavage, and M. B. Abou-Donia. 2004. Depleted and Natural Uranium: Chemistry and Toxicological Effects. Journal of Toxicology and Environmental Health, Part B 7:297-317. doi: $10.1080 / 10937400490452714$.

Crancon, P., and J. van der Lee. 2003. Speciation and Mobility of Uranium (VI) in Humic Containing Soils. Radiochimica Acta 91:673-679.

Crancon, P., E. Pili, and L. Charlet. 2010. Uranium Facilitated Transport by WaterDipersable Colloids in the Field and Soil Columns. Science of the Total Environment 408:2118-2128. doi: 10.1016/j.scitotenv.2010.01.061.

Dang, D. H., W. Wang, P. Pelletier, A. J. Poulain, and R. D. Evans. 2018. Uranium Dispersion from U Tailings and Mechanisms Leading to U Accumulation in Sediments: Insights from Biogeochemical and Isotopic Approaches. Science of the Total Environment 610-611: 880-891. doi: 10.1016/j.scitotenv.2017.08.156.

Du, L., S. Li, X. Li, P. Wang, Z. Huang, Z. Tan, C. Liu, J. Liao, and N. Liu. 2017. Effect of Humic Acid on Uranium(VI) Retention and Transport through Quartz Columns with Varying $\mathrm{pH}$ and Anion Type. Journal of Environmental Radioactivity 177:142-150. doi: 10.1016/j.jenvrad.2017.06.016.

Dushenkov, S., D. Vasudev, Y. Kapulnik, D. Gleba, D. Fleisher, K. C. Ting, and B. Ensley. 1997. Removal of Uranium from Water Using Terrestrial Plants. Environmental Science and Technology 31 (12): 3468-3474.

Echevarria, G., M. I. Sheppard, and J. L. Morel. 2001. Effect of pH on the Sorption of Uranium in Soils. Journal of Environmental Radioactivity 53:257-264.

Elless, M. P., and S. Y. Lee. 1998. Uranium Solubility of Carbonate-Rich UraniumContaminated Soils. Water, Air, and Soil Pollution 107:147-162. 
Farr, J. V., I. J. Faber, A. Ganguly, W. A. Martin, and S. L. Larson. 2016. SimulationBased Costing for Early Phase Life Cycle Cost Analysis: Example Application to an Environmental Remediation Project. The Engineering Economist 61:207222. doi: 10.1080/o013791X.2015.1062582.

Gavrilescu, M., L. V. Pavel, and I. Cretescu. 2009. Characterization and Remediation of Soils Contaminated with Uranium. Journal of Hazardous Materials 163:475510. doi: 10.1016/j.jhazmat.2008.07.103.

Golovich, E. C., D. M. Wellman, R. J. Serne, and C. C. Bovaird. 2011. Summary of Uranium Solubility Studies in Concrete Waste Forms and Vadose Zone Environments. PNNL-20726. Richland, WA: Pacific Northwest National Laboratory.

Gorby, Y. A., and D. R. Lovely. 1992. Enzymatic Uranium Precipitation. Environmental Science and Technology 26:205-207.

Gorman-Lewis, D., P. C. Burns, and J. B. Fein. 2008. Review of Uranyl Mineral Solubility Measurements. Journal of Chemical Thermodynamics 40:335-352. doi: 10.1016/j.jct.2007.12.004.

Handley-Sidhu, S., P. J. Worsford, C. Boothman, J. R. Lloyd, R. Alvarez, F. R. Livens, D. J. Vaughan, and M .J. Keith-Roach. 2009a. Corrosion and Fate of Depleted Uranium Penetrators Using Progressively Anaerobic Conditions in Estuarine Sediment. Environmental Science and Technology 43:350-355.

Handley-Sidhu, S., P. J. Worsford, F. L. Livens, D. J. Vaughan, J. R. Lloyd, C. Boothman, M. Sajih, R. Alvarez, and M. J. Keith-Roach. 2009b. Biogeochemical Controls on the Corrosion of Depleted Uranium Alloy in Subsurface Soils. Environmental Science and Technology 43:6177-6183.

Handley-Sidhu, S., N. D. Bryan, P. J. Worsford, D. J. Vaughan, F. R. Livens, and M. J. Keith-Roach. 2009c. Corrosion and Transport of Depleted Uranium in Sand-Rich Environments. Chemosphere 77:1434-1439.

Handley-Sidhu, S., M. J. Keith-Roach, J. R. Lloyd, and D. J. Vaughan. 2010. A Review of the Environmental Corrosion, Fate and Bioavailability of Munitions Grade Depleted Uranium. Science of the Total Environment 408:5690-5700.

Harguindeguy, S., P. Crancon, F. Pointurier, M. Potin-Gautier, and G. Lespes. 2014. Isotopic Investigation of the Colloidal Mobility of Depleted Uranium in a Podzolic Soil. Chemosphere 103:343-348. doi:10.1016/j.chemosphere.2013.12.033.

Honeyman, B. D., and J. F. Ranville. 2002. Colloid Properties and Their Effects on Radionuclides Transport through Soils and Groundwaters. In Geochemistry of Soil Radionuclides. Soil Science Society of America Special Publication 59, 131163.

Huang, J. W., M. J. Blaylock, Y. Kapulnick, and B. Ensley. 1998. Phytoremediation of Uranium-Contaminated Soils: Role of Organic Acids in Triggering Uranium Hyperaccumulation in Plants. Environmental Science and Technology 32 (13): 2004-2008. doi: 10.1021/es971027u. 
Johnson, B. E., V. F. Medina, and D. Cuniff. 2006. Evaluation of the Movement of Depleted Uranium Using a Distributed Watershed Model. Practice Periodical of Hazardous, Toxic, and Radioactive Waste Management 10 (3): 179-189.

Johnson, W. H., B. J. Buck, H. Brogonia, and A. Brock. 2004. Variations in Depleted Uranium Sorption and Solubility with Depth in Arid Soils. Soil and Groundwater Contamination: An International Journal 13:533-544.

doi: $10.1080 / 10588330490519428$.

Jung, H. B., M. I. Boyanov, H. Konishi, Y. Sun, and B. Mishra. 2012. Redox Behavior of Uranium at the Nanoporous Aluminum Oxide-Water Interface: Implications for Uranium Remediation. Environmental Science and Technology 46:7301-7309. doi: 10.1021/es2044163

Kaplan, D. I., and S. M. Serkiz. 2001. Quantification of Thorium and Uranium Sorption to Contaminated Sediments. Journal of Radioanalytical and Nuclear Chemistry 248:529-535.

Keele, M. J., E. J. Rapacki, W. J. Bruchey, Jr. 1989. High Velocity Performance of a Uranium Alloy Long Rod Penetrator. Aberdeen Proving Ground, Maryland: Army Ballistic Research Laboratory.

Larner, B. L., A. J. Seen, and A. T. Townsend. 2006. Comparative Study of Optimized BCR Sequential Extraction Scheme and Acid Leaching of Elements in the Certified Reference Materials NIST 2711. Analytica Chimica Acta 556:444-449.

Larson, S. L., J. H. Ballard, A. J. Bednar, M. G. Shettlemore, C. Christodoulatos, R. Manis, J. C. Morgan, and M. P. Fields. 2004. Evaluation of Thorium-232 Contamination at Kirtland Air Force Base, Defense Nuclear Weapons School, Training Site 4. ERDC/EL-TR-04-15. Vicksburg, MS: U.S. Army Engineer Research and Development Center.

Larson S. L., J. H. Ballard, V. F. Medina, M. Thompson, G. J. O’Connor, C. Griggs, and C. C. Nestler. 2009. Separation of Depleted Uranium from Soil. ERDC/EL TR-09-1. Vicksburg, MS: U.S. Army Engineer Research and Development Center.

Larson, S. L., V. F. Medina, J. Ballard, C. Griggs, M. Wynter, D. Mackie, B. King, and C. C. Nestler. 2012. Large-Scale Physical Separation of Depleted Uranium from Soil. ERDC/EL TR-12-25. Vicksburg, MS: U.S. Army Engineer Research and Development Center.

Lenhart, J. J., S. E. Cabaniss, P. MacCarthy, and B. D. Honeyman. 200o. Uranium(VI) Complexation with Citric, Humic, and Fulvic Acids. Radiochimica Acta 88:345353 .

Lind, O. C., B. Salbu, L. Skipperud, K. Janssens, J. Jaroszewicz, and W. De Nolf. 2009. Solid State Speciation and Potential Bioavailability of Depleted Uranium Particles from Kosovo and Kuwait. Journal of Environmental Radioactivity 100:301-307. doi: 10.1016/j.jenvrad.2008.12.018.

McClain, D. E., and A. C. Miller. 2007. Depleted Uranium Biological Effects: Introduction and Early In Vitro and In Vivo Studies. In Depleted Uranium. Properties, Uses, and Health Consequences, ed. A. C. Miller, 1-20. Boca Raton, FL: CRC Press of Taylor \& Francis Group. 
Mellini, M., and F. Riccobono. 2005. Chemical and Mineralogical Transformations Caused by Weathering in Anti-Tank DU Penetrators ("The Silver Bullets") Discharged During the Kosovo War. Chemosphere 60:1246-1252.

Murphy, W. M., and E. L. Shock. 1999. Environmental Aqueous Geochemistry of Actinides. Reviews of Mineralogy and Geochemistry 38 (1): 221-51.

Murphy R. J., J. J. Lenhart, and B. D. Honeyman. 1999. The Sorption of Thorium (IV) and Uranium (VI) to Hematite in the Presence of Natural Organic Matter. Colloids and Surfaces A: Physicochemical and Engineering Aspects 157 (1-3): 47-62.

Noubactep, C., A. Schoner, and G. Meinrah. 2006. Mechanism of Uranium Removal from the Aqueous Solution by Elemental Iron. Journal of Hazardous Materials 132 $(2-3): 202-212$.

Oliver, I. W., M. C. Graham, A. B. MacKenzie, R. M. Ellam, and J. G. Farmer. 2008a. Depleted Uranium Mobility across a Weapons Testing Site: Isotopic Investigation of Porewater, Earthworms, and Soils. Environmental Science and Technology 42:9158-9164.

- - 2008b. Distribution and Partitioning of Depleted Uranium (DU) in Soils at Weapons Test Ranges-Investigations Combining the BCR Extraction Scheme and Isotopic Analysis. Chemosphere 72:932-939. doi: 10.1016/j.chemosphere.2008.03.029.

Payne, T. E., and J. R. Harries. 2000. Adsorption of Cs and U(VI) on the Soils of the Australian Arid Zone. Radiochimica Acta 88:799-802.

Rael, J. E. 1997. Depleted Uranium Migration at Yuma Proving Ground. Ph.D. dissertation, University of New Mexico, Albuquerque.

Ribera, D., F. Labrot, G. Tisnerat, J.-F. Narbonne. 1996. Uranium in the Environment: Occurrence, Transfer, and Biological Effects. Review of Environmental Contamination and Toxicology 146:53-89.

Rout, S., P. M. Ravi, A. Kumar, R. M. Tripathi. 2015. Study on Speciation and SalinityInduced Mobility of Uranium from Soil. Environmental Earth Science 74:22732281. doi: 10.1007/s12665-015-4218-9.

Runde, W., M. P. Neu, S. D. Conradson, D. Li, M. Lin, D. M. Smith, C. E. Van-Pelt, and Y. Xu. 2002. Geochemical Speciation of Actinides in Soil and Solution. In Geochemistry of Soil Radionuclides. Soil Science Society of America Special Publication 59, 45-59.

Salbu, B., K. Janssens, O. C. Lind, K. Proost, L. Gijsels, and P. R. Danesi. 2005. Oxidation States of Uranium in Depleted Uranium Particles from Kuwait. Journal of Environmental Radioactivity 78:125-135. doi: 10.1016/j.jenvrad.2004.04.001.

Schimmack, W., U. Gerstmann, W. Schultz, and G. Geipel. 2007. Long-Term Corrosion and Leaching of Depleted Uranium. Radiation and Environmental Biophysics 46:221-227. 
Senko, J. M., J. D. Istok, J. M. Suflita, and L. R. Krumholz. 2002. In-Situ Evidence for Uranium Immobilization and Remobilization. Environmental Science and Technology 36:1491-1496. doi: 10.1021/es011240x.

Tamasi, A. L., K. S. Boland, K. Czerwinski, J. K. Ellis, S. A. Kozimor, R. L. Martin, A. L. Pugmire, D. Reilly, B. L. Scott, A. D. Sutton, G. L. Wagner, J. R. Walensky, and M. P. Wilkerson. 2015. Oxidation and Hydration of $\mathrm{U}_{3} \mathrm{O}_{8}$ Materials following Controlled Exposure to Temperature and Humidity. Analytical Chemistry 87:4210-4217. doi: 10.1021/ac504105t.

Tessier, A., P. G. C. Campbell, M. Bisson. 1979. Sequential Extraction Procedure for the Speciation of Particulate Trace Metals. Analytical Chemistry 51:844-851.

Török, S., J. Osán, L. Vincze, S. Kurunczi, G. Tamborini, and M. Betti. 2004.

Characterization and Speciation of Depleted Uranium in Individual Soil Particles Using Microanalytical Methods. Spectrochimica Acta, Part B 59:689-699. doi: 10.1016/j.sab.2004.02.003.

U.S. EPA (United States Environmental Protection Agency). 1999. Test Methods for Evaluating Solid Waste, Physical/Chemical Methods. SW-846. Washington, DC: U.S. Environmental Protection Agency.

- 2006. Depleted Uranium: Technical Brief. EPA-402-R-06-011. Washington, DC: Office of Air and Radiation.

Unz, R. J., J. P. McCown, C. A. Waggoner, S. L. Larson, and J. H. Ballard. 2018. Development and Characterization of Small-Scale Washing Systems for Removal of Depleted Uranium Oxides. ERDC/EL TR-18-1. Vicksburg, MS: U.S. Army Engineer Research and Development Center.

Waisner, S. A., A. B. Morrow, C. C. Nestler, and V. F. Medina. 2011. Chemical Degradation of PCBs in Alaskan Soils. ERDC/EL TR-11-3. Vicksburg, MS: U.S. Army Engineer Research and Development Center.

Walters, J., J. Mackey, K. Maki, R. Northcutt, J. Farr, A. Martin, S. Larson, J. Ballard, and C. Nestler. 2014. Cost Analysis of Remediation Systems for Depleted Uranium. ERDC/EL TR-14-5. Vicksburg, MS: U.S. Army Engineer Research and Development Center.

Ward, T. J., and K. A. Stevens. 1994. Modeling Erosion and Transport of Depleted Uranium, Yuma Proving Ground, Arizona. WRRI Report No. 286. Las Cruces, NM: New Mexico Water Resource Research Institute.

Wronkiewicz, D., J. K. Bates, T. J. Gerding, E. Veleckis, and B. S. Tani. 1992. Uranium Release and Secondary Phase Formation during Unsaturated Testing of $\mathrm{UO}_{2}$ at $90^{\circ}$ C. Journal of Nuclear Material 190:107-127.

Xiang, S-R, A. Doyle, P. A. Holden, and J. P. Schimel. 2008. Drying and Rewetting Effects on $\mathrm{C}$ and $\mathrm{N}$ Mineralization and Microbial Activity in Surface and Subsurface California Grassland Soils. Soil Biology and Biochemistry 40:2281-2289. 


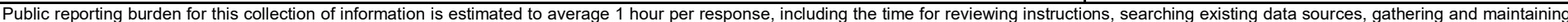

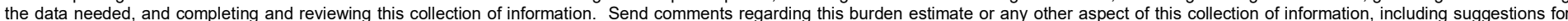

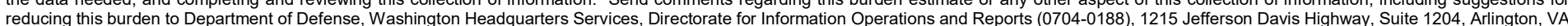

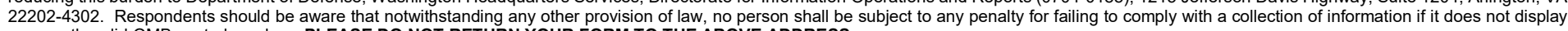
a currently valid OMB control number. PLEASE DO NOT RETURN YOUR FORM TO THE ABOVE ADDRESS.
1. REPORT DATE (DD-MM-YYYY) June 2018

4. TITLE AND SUBTITLE

Corrosion and Migration of Zero-Valent Depleted Uranium Products in Soil

\section{AUTHOR(S)}

Victor F. Medina, Michelle Wynter, Steven L. Larson, Robert D. Moser, and Catherine C. Nestler

\section{DATES COVERED (From - To)}

\section{5a. CONTRACT NUMBER}

5b. GRANT NUMBER

5c. PROGRAM ELEMENT NUMBER

0603728A

5d. PROJECT NUMBER

5e. TASK NUMBER

5f. WORK UNIT NUMBER

8. PERFORMING ORGANIZATION REPORT NUMBER

ERDC TR-18-5

U.S. Army Engineer Research and Development Center (ERDC)

Environmental Laboratory (EL)

3909 Halls Ferry Rd.

Vicksburg, MS 39180

\section{SPONSORING / MONITORING AGENCY NAME(S) AND ADDRESS(ES)}

Headquarters, U.S. Army Corps of Engineers

Washington, DC 20314-1000

10. SPONSOR/MONITOR'S ACRONYM(S)

USACE

11. SPONSOR/MONITOR'S REPORT NUMBER(S)

\section{DISTRIBUTION / AVAILABILITY STATEMENT}

Approved for public release; distribution is unlimited.

\section{SUPPLEMENTARY NOTES}

Environmental Quality/Installations (EQ/I)

\section{ABSTRACT}

Zero-valent metallic depleted uranium (DU) penetrators exposed in the environment after firing frequently undergo corrosion. Unlike previous field studies, this report evaluates metallic DU corrosion in a controlled laboratory setting using a 28 day wet-dry cycling method to simulate environmental corrosion. Carried out in construction-grade sand, the study evaluated the effect of three solutions: deionized (DI) water, $3.5 \%$ salt $(\mathrm{NaCl})$ solution, and an acid solution. Two oxidation products in the reactors were noted at 14 days, both in the sand and on the penetrator. Oxidation product migrated to the sand media; the higher percentage of migration came from the corrosion fluid that produced the least amount of corrosion. Changes in mass percentages of uranium and oxygen correlated with density changes, as evidenced by relative brightness, to show differences in corrosion. Other elements (sodium, magnesium, iron, and calcium) increased in mass percentage with increasing corrosion. Five soil types were also used to corrode DU. Multiple soil physical and chemical characteristics appear to contribute to differences in the rates of corrosion, including soil $\mathrm{pH}$, percentage of soil fines, and total organic carbon content. These studies suggest that limiting moisture and salt exposure could reduce corrosion of exposed DU and subsequent migration.

\section{SUBJECT TERMS}

Corrosion, Depleted uranium, Oxidation, Salinity, Soil absorption and adsorption, Soil pollution, Soils--Classification

\section{SECURITY CLASSIFICATION OF:}

\section{a. REPORT}

Unclassified

\section{b. ABSTRACT}

Unclassified

\section{c. THIS PAGE}

Unclassified

\begin{tabular}{c|c|} 
17. LIMITATION & 18. NUMBER \\
OF ABSTRACT & OF PAGES \\
SAR & 58
\end{tabular}

19a. NAME OF RESPONSIBLE PERSON

19b. TELEPHONE NUMBER (include area code) 